\title{
Environmental drivers of coccolithophore abundance and calcification across Drake Passage (Southern Ocean)
}

\author{
Anastasia Charalampopoulou ${ }^{1}$, Alex J. Poulton ${ }^{2}$, Dorothee C. E. Bakker ${ }^{3}$, Mike I. Lucas ${ }^{4}$, Mark C. Stinchcombe ${ }^{2}$, \\ and Toby Tyrrell ${ }^{1}$ \\ ${ }^{1}$ Ocean and Earth Science, National Oceanography Centre Southampton, University of Southampton, \\ Southampton, SO14 3ZH, UK \\ ${ }^{2}$ Ocean Biogeochemistry and Ecosystems, National Oceanography Centre, Southampton, SO14 3ZH, UK \\ ${ }^{3}$ School of Environmental Sciences, University of East Anglia, Norwich Research Park, NR4 7TJ, UK \\ ${ }^{4}$ Marine Research Institute, University of Cape Town, Rondebosch, South Africa \\ Correspondence to: Alex J. Poulton (alex.poulton@noc.ac.uk)
}

Received: 13 April 2016 - Published in Biogeosciences Discuss.: 20 April 2016

Revised: 8 September 2016 - Accepted: 25 September 2016 - Published: 1 November 2016

\begin{abstract}
Although coccolithophores are not as numerically common or as diverse in the Southern Ocean as they are in subpolar waters of the North Atlantic, a few species, such as Emiliania huxleyi, are found during the summer months. Little is actually known about the calcite production $(\mathrm{CP})$ of these communities or how their distribution and physiology relate to environmental variables in this region. In February 2009, we made observations across Drake Passage (between South America and the Antarctic Peninsula) of coccolithophore distribution, $\mathrm{CP}$, primary production, chlorophyll $a$ and macronutrient concentrations, irradiance and carbonate chemistry. Although $\mathrm{CP}$ represented less than $1 \%$ of total carbon fixation, coccolithophores were widespread across Drake Passage. The B/C morphotype of E. huxleyi was the dominant coccolithophore, with low estimates of coccolith calcite $\left(\sim 0.01 \mathrm{pmol} \mathrm{C}\right.$ coccolith $\left.^{-1}\right)$ from biometric measurements. Both cell-normalised calcification $(0.01-$ $\left.0.16 \mathrm{pmol} \mathrm{C} \mathrm{cell}^{-1} \mathrm{~d}^{-1}\right)$ and total CP $\left(<20 \mu \mathrm{mol} \mathrm{C} \mathrm{m}{ }^{-3} \mathrm{~d}^{-1}\right)$ were much lower than those observed in the subpolar North Atlantic where E. huxleyi morphotype A is dominant. However, estimates of coccolith production rates were similar (0.1-1.2 coccoliths cell $\left.{ }^{-1} \mathrm{~h}^{-1}\right)$ to previous measurements made in the subpolar North Atlantic. A multivariate statistical approach found that temperature and irradiance together were best able to explain the observed variation in species distribution and abundance (Spearman's rank correlation $\rho=0.4, p<0.01)$. Rates of calcification per cell and coccolith production, as well as community CP and E. hux-
\end{abstract}

leyi abundance, were all positively correlated $(p<0.05)$ to the strong latitudinal gradient in temperature, irradiance and calcite saturation states across Drake Passage. Broadly, our results lend support to recent suggestions that coccolithophores, especially E. huxleyi, are advancing polewards. However, our in situ observations indicate that this may owe more to sea-surface warming and increasing irradiance rather than increasing $\mathrm{CO}_{2}$ concentrations.

\section{Introduction}

As major pelagic calcifiers, coccolithophores have received significant interest over the last couple of decades, mainly due to their importance in the marine carbon cycle where they contribute to both the organic carbon (biological) and carbonate pumps. Emiliania huxleyi, the most widespread coccolithophore species, has been extensively studied in laboratory cultures in terms of its physiology (e.g. Paasche, 2002), and there is now a growing number of field studies examining its eco-physiology (e.g. Harley et al., 2010; Poulton et al., 2010, 2011, 2013, 2014; Charalampopoulou et al., 2011; Young et al., 2014).

There are currently several distinct morphotypes of $E$. huxleyi recognised in the literature, each exhibiting slightly different characteristics in terms of their coccoliths; the main morphotypes are currently termed A, B, B/C and R (Young et al., 2003, 2014; Poulton et al., 2011). Those most com- 
monly available in laboratory culture are morphotypes A and $\mathrm{B}$ (Paasche, 2002), although strains of $\mathrm{B} / \mathrm{C}$ are now being isolated and studied from the Southern Ocean (e.g. Cook et al., 2011, 2013). Morphotype A forms blooms in the subpolar North Atlantic and Norwegian coastal waters, whereas morphotype B is primarily found in the North Sea (van Bleijswijk et al., 1991; Holligan et al., 1993; Paasche et al., 1996). The eco-physiology of these two morphotypes is thus relatively well studied and seasonally shallow mixed layers, high temperatures and high irradiances are often associated with their large-scale monospecific blooms (Tyrrell and Merico, 2004; Raitsos et al., 2006).

Morphotype $\mathrm{B} / \mathrm{C}$ is the dominant morphotype of $E$. huxleyi found in the colder waters of the Southern Ocean (Cubillos et al., 2007; Cook et al., 2011, 2013; Poulton et al., 2011, 2013). A number of observations have shown that $E$. huxleyi $\mathrm{B} / \mathrm{C}$ is widespread in the Atlantic, Indian and Pacific sectors of the Southern Ocean, except close to the Antarctic continent where coccolithophores are absent (Cubillos et al., 2007; Findlay and Giraudeau, 2000; Gravalosa et al., 2008; Mohan et al., 2008; Hinz et al., 2012; Saavedra-Pellitero et al., 2014; Malinverno et al., 2015). In contrast with the wellstudied morphotypes A and B, most of the current knowledge on morphotype $\mathrm{B} / \mathrm{C}$ regards the different morphological characteristics of its coccoliths, which have a lower calcite content relative to their northern hemispheric counterparts (Cook et al., 2011; Poulton et al., 2011). Furthermore, the $\mathrm{B} / \mathrm{C}$ morphotype is physiologically and genetically distinct from morphotype A (Cook et al., 2011, 2013), and in 2008 it dominated a Patagonian Shelf bloom which occurred in waters with low temperatures $\left(<8^{\circ} \mathrm{C}\right)$, high macronutrient concentrations (e.g. nitrate $>10 \mu \mathrm{mol} \mathrm{kg}{ }^{-1}$ ) and high irradiances (Poulton et al., 2011, 2013; Balch et al., 2014). This dominance has now been suggested to result in low integrated calcite concentrations within bloom waters on the Patagonian Shelf (Poulton et al., 2013; Balch et al., 2014).

Laboratory and field studies on E. huxleyi show that calcification in this species depends strongly on irradiance and is also stimulated by nutrient stress (Paasche, 2002; Zondervan, 2007; Müller et al., 2008), which give important clues to its response to changing nutrient and light conditions in the future ocean. However, the response of this species to increased $p \mathrm{CO}_{2}$ (and associated reduced $\mathrm{pH}$, i.e. ocean acidification) in terms of growth and calcification rates appears closely related to the strain (both within and between morphotypes) studied (Langer et al., 2009, 2011) and the length of exposure to high $p \mathrm{CO}_{2} /$ low pH (Lohbeck et al., 2012). Moreover, the sensitivity of $E$. huxleyi to elevated $p \mathrm{CO}_{2}$ also depends on irradiance (Feng et al., 2008; Zondervan et al., 2002) and nutrient conditions (Sciandra et al., 2003; Delille et al., 2005). Future oceanic changes are likely to happen simultaneously (Gruber, 2011) due to sea-surface warming (Barnett et al., 2005), shallowing of the mixed layer (Levitus et al., 2000) and ocean acidification (Orr et al., 2005). Thus, it is important to validate the findings of laboratory ex- periments with field studies in order to understand how natural coccolithophore populations might respond to simultaneous changes in environmental variables. Tyrrell and Charalampopoulou (2009) provided data on basic hydrography as well as coccolithophore composition, coccolith biometry and calcification, while Bakker et al. (2013) provided data on macronutrients and carbonate chemistry.

In natural coccolithophore populations, bulk community rates of calcite production (CP) are influenced by both cell numbers (a product of growth and mortality of the population) and variability in the rate of calcification per cell (a function of environmental conditions and species composition) (Poulton et al., 2010, 2014; Charalampopoulou et al., 2011). Cellular rates of calcification are dependent on both the calcite content of individual coccoliths and the rate of coccolith production. Rather than examining bulk CP and comparing it to environmental factors, a more appropriate approach is to consider cellular levels of calcification in the form of cell-normalised rates (cell-CF), which when normalised to coccolith calcite content allow an estimate of coccolith production rates (Poulton et al., 2010, 2013; Charalampopoulou et al., 2011). The calcite content of individual coccoliths is determined by their volume/shape and distal shield length (DSL) (Young and Ziveri, 2000). Hence, with information on the species (or morphotype) present and measurements of coccolith size it is possible to estimate coccolith calcite content (e.g. Poulton et al., 2011; Young et al., 2014; Jin et al., 2016). Together, these three metrics (cell-CF, coccolith calcite, coccolith production rates) allow for greater insight into the calcification of natural communities than can be obtained from bulk CP measurements alone.

The Southern Ocean has naturally low-calcite saturation states $\left(\Omega_{\mathrm{C}}\right)$, due to low seawater temperatures, and will be among the first oceanic regions to experience widespread $\mathrm{CaCO}_{3}$ under-saturation at the surface (Hauri et al., 2015). Nevertheless, there have been suggestions that the distribution of E. huxleyi has recently extended polewards in the Southern Ocean (Winter et al., 2014; but see also Malinverno et al., 2015), with a north to south progression from high to low coccolith-calcite-containing morphotypes as temperature and $\Omega_{\mathrm{C}}$ decline (Cubillos et al., 2007), often regarded as indicating a reduction in calcification rates in Antarctic waters. In this context, the lack of information on coccolithophore calcification in the Southern Ocean is a significant gap in our understanding of the effects of future changes on the marine carbon cycle.

The main aims of this study were to investigate the distribution and calcification of coccolithophore populations across Drake Passage in the Southern Ocean and to examine how these relate to environmental variables (i.e. temperature, salinity, nutrients, irradiance and carbonate chemistry parameters). In order to examine changes in calcification, we made estimates of cellular coccolith production rates (Poulton et al., 2010, 2013; Charalampopoulou et al., 2011) from cell$\mathrm{CF}$ and estimates of coccolith calcite content using biometric 
measurements (Poulton et al., 2011; Young et al., 2014; Jin et al., 2016). Examination of such trends in cellular calcification across environmental gradients allows for changes due to variability in both cell numbers and cellular calcification to be taken into account: bulk measurements of (community) CP may be driven by variability in both (Poulton et al., 2010, 2014).

\section{Methods}

\subsection{Study area}

Drake Passage is characterized by strong eastward flow of the Antarctic Circumpolar Current (ACC) driven by strong westerly winds. The boundaries of the ACC are defined by oceanic fronts, where rapid changes in temperature and salinity occur over short distances. The northern boundary of the ACC is the Subtropical Front (STF), which separates warm subtropical waters from cold subantarctic waters (Orsi et al., 1995; Pollard et al., 2002). South of the STF, the three fronts associated with the ACC are, from north to south, the Subantarctic Front (SAF), the Polar Front (PF) and the Southern ACC Front (SACCF). These three fronts define the three major zones of the ACC (Fig. 1). The area between the STF and the SAF is often referred to as the Subantarctic Zone, while between the SAF and the PF is the Polar Frontal Zone and between the PF and the SACCF is the Antarctic Zone (Orsi et al., 1995; Pollard et al., 2002). A fourth zone, located between the southern boundary of the ACC (SB) and the Antarctic continent, is referred to as the Continental Zone (Whitworth III, 1980). The positions of these fronts during the two transects of the cruise are shown in Fig. 1. Dynamic height (Sun and Watts, 2001), as well as the hydrographic criteria of Orsi et al. (1995), was used to determine the positions of the fronts (S. Close and G. Evans, unpublished data, 2009).

\subsection{Sampling}

Sampling was conducted during cruise JC031 (3 February3 March 2009) on board the RRS James Cook, from Punta Arenas, Chile, to the Antarctic Peninsula (Transect 1) and back to the Falklands (Transect 2) (Fig. 1). A stainless steel conductivity-temperature-depth (CTD) rosette was deployed at every sampling station and samples from five depths were collected from the upper $100 \mathrm{~m}$ of the water column $(5,10,50,75$ and $100 \mathrm{~m})$. Water samples for macronutrients, chlorophyll $a(\mathrm{Chl} a)$ and ancillary parameters (temperature, salinity, irradiance) were collected at a total of 61 stations. Samples for coccolithophore abundance and diversity were collected at 53 stations, carbonate chemistry parameters at 51 stations and samples for $\mathrm{CP}$ and primary production (PP) were collected at 20 stations (red circles in Fig. 1).

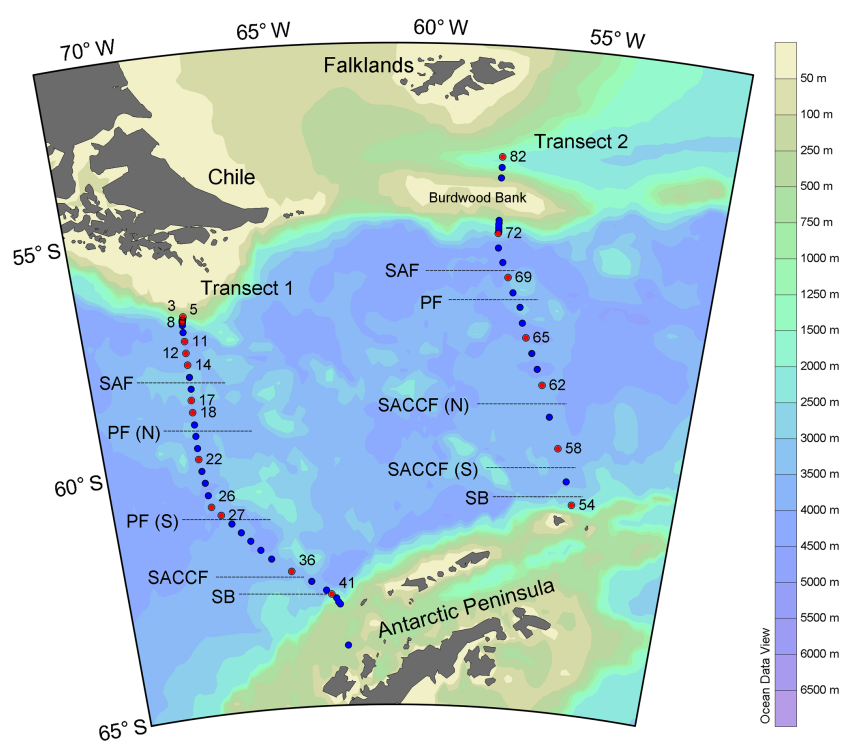

Figure 1. JC31 cruise track, showing Transect 1 (Chile to Antarctica) and Transect 2 (Antarctica to Falklands). Blue and red circles indicate sampling stations. Red circles are numbered and indicate stations where calcification rates were also measured. The locations of the following fronts are shown on each transect: Subantarctic Front (SAF), Polar Front (PF), Southern Antarctic Circumpolar Current Front (SACCF) and southern boundary of the ACC (SB). Where two possible locations or two branches of a front were observed, these are denoted with a northern $(\mathrm{N})$ or southern $(\mathrm{S})$ suffix.

\subsection{Coccolithophore community}

Water samples $(1 \mathrm{~L})$ from up to five CTD depths over the upper $100 \mathrm{~m}(5,10,50,75$ and $100 \mathrm{~m})$ were gently filtered onto Millipore Isopore membrane filters $(25 \mathrm{~mm}$ diameter, $1.2 \mu \mathrm{m}$ pore size), with a $25 \mathrm{~mm}$ diameter circle of $10 \mu \mathrm{m}$ nylon mesh acting as a backing filter to achieve even distribution of cells. The membrane filters were rinsed with trace ammonia solution ( $\mathrm{pH}$ 9-10) to remove salts, oven dried overnight at $30^{\circ} \mathrm{C}$ and stored in the dark in sealed Petri dishes. A radially cut portion of each filter was mounted on an aluminium stub and gold-coated. For each filter, 225 fields of view (FOV = images), together covering an area of $\sim 0.9 \mathrm{~mm}^{2}$ of the filter paper, were taken at $5000 \times$ magnification along a predefined meander-shaped transect, using a Scanning Electron Microscope (Leo 1450VP, Carl Zeiss, Germany) combined with SmartSEM software. For each sample, both complete coccospheres and detached coccoliths were enumerated until 300 of each were reached or until all FOV had been counted. The SmartSEM software was set to scan for zero overlap between FOVs. To avoid double-counting of specimens that were on the FOV margins, only cells at the top and right edges of each FOV were counted but not at the bottom and left edges. The number of FOVs counted was used to calculate the area of the filter covered (the size of one FOV was $4.054 \times 10^{-3} \mathrm{~mm}^{2}$ ). 
Both coccospheres and coccoliths were identified to species level following Young et al. (2003) and, in the case of $E$. huxleyi, to recognisable morphotypes based on distal shield characteristics (see Young et al., 2003 and Poulton et al., 2011). The abundance of coccospheres and coccoliths for each species was calculated as

$$
\begin{aligned}
& \text { Coccospheres or detached coccoliths } \mathrm{mL}^{-1} \\
& \quad=C \times(F / A) / V
\end{aligned}
$$

where $C$ is the total number of coccospheres or coccoliths counted, $A$ is the area investigated $\left(\mathrm{mm}^{2}\right), F$ is the total filter area $\left(\mathrm{mm}^{2}\right)$ and $V$ is the volume filtered $(\mathrm{mL})$. Standard error (SE) of the coccolithophore counts was calculated as the square root of the counted number of cells divided by the equivalent volume of sample investigated (area of FOV $\times V / A$ ) (Taylor, 1982). Ninety-five per cent (95\%) confidence limits of coccolithophore abundance were obtained by multiplying the standard error by the appropriate $z$ score where more than 30 cells were counted, and so the uncertainty was $\pm 1.96 \times \mathrm{SE}$ cells $\mathrm{mL}^{-1}$. When less than 30 cells were counted the appropriate $t$ values were used instead of $z$ scores (Fowler et al., 1998).

\subsection{Coccolith morphology and calcite content}

Detached coccoliths were predominantly ( $>99 \%$ numerically) from the species Emiliania huxleyi. The DSLs of 50 E. huxleyi detached coccoliths were measured in each of the 20 stations where $\mathrm{CP}$ was also measured, using the image processing software ImageJ (Abramoff et al., 2004; Young et al., 2014). At the same time, each coccolith was classified as either morphotype A, B or B/C following Young et al. (2003). Only type $B / C$ was found in our samples, as identified by its delicate distal shield elements and central area open or with a thin plate. It should be noted that Hagino et al. (2011) have classified open central area type $\mathrm{B} / \mathrm{C}$ as type $\mathrm{O}$, although we did not differentiate these in this study. Coccolith calcite content ( $\mathrm{pmol} \mathrm{C}$ or $\mathrm{CaCO}_{3}$ coccolith $^{-1}$ ) was calculated from the volume of each coccolith and the density $\left(2.7 \mathrm{pg} \mathrm{\mu m}^{-3}\right)$ and molecular weight $\left(100 \mathrm{~g} \mathrm{~mol}^{-1}\right)$ of calcite. Coccolith volume was a function of DSL and a shape-dependent constant, $k_{\mathrm{s}}(0.015$ for type $\mathrm{B} / \mathrm{C}$; Poulton et al., 2011), following the equations of Young and Ziveri (2000):

$$
\begin{aligned}
& \text { coccolith calcite }\left(\mathrm{pmol} \mathrm{C} \text { or } \mathrm{CaCO}_{3} \text { coccolith }^{-1}\right) \\
& =k_{\mathrm{S}} \times \mathrm{DSL}^{3} \times \text { calcite density } / \text { molecular weight. }
\end{aligned}
$$

\subsection{Calcite production and primary production}

Water samples for rate measurements were collected before dawn (or early in the morning in a few cases), from 3 to 5 light depths within the upper $100 \mathrm{~m}$ of the water column (including $0.1-1.5,7,14,33$ and $55 \%$ of incident photosynthetically active radiation, PAR) or only from surface waters $(55 \%)$. Daily rates of PP and CP were determined following the "micro-diffusion" technique of Paasche and Brubak (1994), as modified by Balch et al. (2000). Water samples (each $150 \mathrm{~mL}, 3$ replicates plus 1 formalin-killed blank) were collected from each light depth, spiked with $100 \mu \mathrm{Ci}$ of ${ }^{14} \mathrm{C}$-labelled sodium bicarbonate (Perkin Elmer, UK) and incubated in on-deck incubators for $24 \mathrm{~h}$. Light depths were replicated using a combination of misty blue and neutral density (Lee filters, UK) filters, and samples were kept at ambient sea-surface temperature by providing a continuous flow of water from the underway supply through the on-deck incubators.

Incubations were terminated by filtration through $25 \mathrm{~mm}$ $0.2 \mu \mathrm{m}$ polycarbonate Isopore filters, which were then acidified with $1 \mathrm{~mL}$ of $1 \%$ phosphoric acid to separate the inorganic fraction (labile, $\mathrm{CP}$ ) from the organic fraction (nonlabile, PP). The inorganic fraction was captured as ${ }^{14} \mathrm{C}-\mathrm{CO}_{2}$ on a $\beta$-phenylethylamine-soaked Whatman GF/A filter and placed in a separate liquid scintillation vial to the original filter. Liquid scintillation cocktail was added to both vials and activity was measured on a TriCarb liquid scintillation counter. Counts were converted to uptake rates using standard methods. The average relative standard deviation (calculated as $\mathrm{SD} \times 100 /$ mean) of triplicate measurements was $6 \%(1-19 \%)$ for PP and $36 \%(2-86 \%)$ for CP, with the higher deviations observed at the base of the euphotic zone were rates of PP and CP were close to zero. The formalin blanks represented a significant proportion of the $\mathrm{CP}$ signal (mean 35\%, range 5-87\%) from the upper $50 \mathrm{~m}$. Blank contribution was even higher below $75 \mathrm{~m}$ and close to Antarctica, where the CP rates were very low. Similar high blank contributions have been reported in other studies (e.g. Poulton et al., 2013, 2014). In contrast, the blanks represented only $\sim 1 \%$ of the PP signal.

\subsection{Cell-specific calcification and coccolith production}

Cell-CF was calculated from total CP and coccolithophore abundance. The associated error was derived from propagation of the individual errors of total CP $( \pm 0$ $\left.3.5 \mu \mathrm{mol} \mathrm{C} \mathrm{m}{ }^{-3} \mathrm{~d}^{-1}\right)$ and coccolithophore abundance $( \pm 0$ 53 cells $\mathrm{mL}^{-1}$ ) following Taylor (1982). Daily coccolith production per cell at each station was calculated from cell-CF and coccolith calcite estimated for each station. The uncertainty in coccolith production rates at each station, due to associated errors in measurements of $\mathrm{CP}$ and coccolithophore abundance, was smaller than the range of coccolith production rates observed due to the relatively high variation in coccolith size. Hence, differences in coccolith production between stations could be attributed mainly to changes in coccolith size rather than to errors associated with the method by which these were estimated. 


\subsection{Environmental variables}

To assess how coccolithophore abundance, species composition and cellular calcification compare to environmental variables, several sets of ancillary measurements were used. These included temperature, salinity, macronutrient (phosphate, nitrate and silicic acid) concentrations, Chl $a$, carbonate chemistry parameters and levels of mixed layer irradiance. Temperature and salinity values were extracted from the Seabird 911+ CTD package. Phosphate, nitrate and silicic acid micro-molar concentrations were determined using a Skalar San++ automatic continuous flow analyser following the methods described by Kirkwood (1996). The errors associated with phosphate, nitrate and silicic acid analysis for this cruise were $\pm 0.01, \pm 0.16$ and $\pm 0.05 \mu \mathrm{mol} \mathrm{kg}{ }^{-1}$, respectively. Water samples $(0.2-0.25 \mathrm{~L})$ for chlorophyll $a$ $(\mathrm{Chl} a)$ analysis were filtered onto Whatman $\mathrm{GFF}(\sim 0.7 \mu \mathrm{m}$ pore size) filters and extracted in $8 \mathrm{~mL} 90 \%$ acetone for $24 \mathrm{~h}$ in the dark at $4{ }^{\circ} \mathrm{C}$. Chl $a$ fluorescence was measured on a Turner Designs AU-10 fluorometer equipped with Welschmeyer (1994) filters and calibrated using a pure Chl $a$ standard (Sigma-Aldrich).

Methodology for dissolved inorganic carbon $\left(C_{\mathrm{T}}\right)$ and total alkalinity $\left(A_{\mathrm{T}}\right)$ sampling and analysis followed Bakker et al. (2009). Water samples were drawn into $500 \mathrm{~mL}$ Schott ${ }^{\circledR}$ SUPRAX borosilicate glass bottles following Dickson et al. (2007) to minimise gas exchange. Samples were usually analysed within $6 \mathrm{~h}$ of collection; when such rapid analysis was not possible the samples were poisoned with $100 \mu \mathrm{L}$ of a saturated solution of mercuric chloride $(7 \mathrm{~g}$ per $100 \mathrm{~mL})$. Three different instruments were used for $C_{\mathrm{T}}$ and $A_{\mathrm{T}}$ analysis. The first was used for $C_{\mathrm{T}}$ only and has an extractor unit built after the design by Robinson and Williams (1992), operating at $4{ }^{\circ} \mathrm{C}$. The second was a VINDTA $3 \mathrm{C}$ combined $C_{\mathrm{T}} / A_{\mathrm{T}}$ instrument (Marianda, Germany) operating at $25^{\circ} \mathrm{C}$. The third was another VINDTA 3C, which was used for determining $A_{\mathrm{T}}$ after $C_{\mathrm{T}}$ analysis on the stand-alone $C_{\mathrm{T}}$ extractor. Water samples were analysed for $C_{\mathrm{T}}$ by the coulometric method after Johnson et al. (1987). The $A_{\mathrm{T}}$ measurements were made by potentiometric titration with the two VINDTA $3 \mathrm{C}$ instruments. Two replicate analyses were made on each sample bottle, and replicate samples were also drawn from the CTD rosette. Certified reference materials (CRMs) (from A. G. Dickson, Scripps Institute of Oceanography) were used for instrument calibration and at least two CRMs were run per station. The precision and accuracy for both $A_{\mathrm{T}}$ and $C_{\mathrm{T}}$ was $<3 \mu \mathrm{mol} \mathrm{kg}{ }^{-1}$. Calcite saturation state $\left(\Omega_{\mathrm{C}}\right), \mathrm{pH}_{\mathrm{T}}(\mathrm{pH}$ on the total scale) and $p \mathrm{CO}_{2}$ were calculated from DIC, TA, nutrients, temperature, salinity and pressure data using the CO2SYS.XLS program for $5 \mathrm{~m}$ depth (Pierrot et al., 2006).

To calculate average daily irradiances over the mixed layer, the mixed layer depth (MLD) was determined as the shallowest depth corresponding to a density difference $\left(\Delta \sigma_{t}\right)$ with surface waters of more than $\Delta \sigma_{t}=0.03$ sigma units, as has been recommended for the Southern Ocean (Dong et al.,
2008). The vertical attenuation coefficient $\left(k_{\mathrm{d}}\right)$ for PAR for downward irradiance at each station was calculated from the monthly averaged (February 2009) light attenuation coefficient at $490 \mathrm{~nm}$ wavelength $\left(k_{490}\right)$ estimate by the MODIS ocean colour satellite (http://oceancolor.gsfc.nasa.gov/) following Rochford et al. (2001):

$k_{\mathrm{d}}=0.0085+1.6243 \times k_{490}$.

The relationship describing the exponential attenuation of downward irradiance $\left(E_{z}\right)$ with depth $(z)$ is

$E_{z}=E_{0} \times \exp \left(-k_{\mathrm{d}} \times z\right)$,

where $E_{0}$ is the instantaneous subsurface irradiance. $E_{0}$ was calculated from minute averaged PAR above the sea-surface (PAR $\left.\mathrm{Pabve}_{\text {arface}}\right)$ data, obtained from the ship-mounted sensors, assuming $E_{0}$ was $55 \%$ of PAR above surface (Kirk, 1983). Daily PAR above surface was calculated as the sum of the minute averaged data over $24 \mathrm{~h}$ and daily irradiance was then calculated at every $1 \mathrm{~m}$ down to the MLD:

$E_{z \text {,daily }}=0.55 \times$ daily $\mathrm{PAR}_{\text {above surface }} \times \exp \left(-k_{\mathrm{d}} \times z\right)$.

The average irradiance over the mixed layer, $E_{\mathrm{MLD}}$

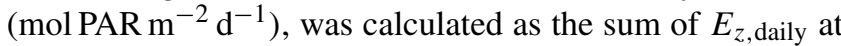
every $1 \mathrm{~m}$ down to the MLD and then divided by the MLD. The euphotic zone depth at each station $\left(Z_{\mathrm{eu}}\right)$, defined as the depth at which $E_{z}$ falls to $1 \%$ of the subsurface value, was equal to an optical depth of 4.6 and hence $Z_{\mathrm{eu}}=4.6 / k_{\mathrm{d}}$ (Kirk, 1983). Comparison of daily PAR data from the ship's sensor with a 32-day composite of MODIS PAR data during the study period showed good agreement and confirmed that daily PAR values were typical for the time of the year and were not biased by weather conditions.

\subsection{Statistical analysis}

Multivariate statistics were used to relate spatial changes in coccolithophore abundance, species composition and cellular calcification to changes in environmental variables. Tyrrell and Charalampopoulou (2009) provided data on basic hydrography as well as coccolithophore composition, coccolith biometry and calcification, while Bakker et al. (2013) provided data on macronutrients and carbonate chemistry. Analysis was carried out following the methods described by Clarke (1993), using E-PRIMER (v. 6.0) (Clarke and Gorley, 2006). Analysis of biotic data was carried out on square-roottransformed $(\sqrt{ } \times)$ species abundances, using Bray-Curtis similarity to determine changes in the abundance of both dominant and less abundant species. Analysis of abiotic data was carried out on power transformed (to reduce skewness and stabilise the variance) and standardised (to bring all variables to comparable scales) values of temperature, salinity, phosphate, nitrate, $\mathrm{pH}_{\mathrm{T}}, \Omega_{\mathrm{C}}, E_{\mathrm{MLD}}$ and $E_{0}$, using Euclidean distance to determine spatial changes in these variables. Principal component analysis (PCA) was carried out on envi- 
ronmental data to reduce the 8-fold variability to a lowdimensional representation of spatial changes in these variables. The BEST routine was used to search for relationships between the biotic and abiotic patterns and to identify which environmental variables(s) explained most of the variation in coccolithophore distribution. Spearman's rank correlations were also used to identify relationships between calcification parameters (coccolith calcite content, coccolith production rate, total and cell-specific calcification) and environmental variables.

\section{Results}

\subsection{Environmental variables and chlorophyll}

Most physicochemical variables exhibited a strong northsouth trend, with temperature and salinity decreasing towards Antarctica (Fig. 2a). Temperature was highest to the south of Chile and the Falkland Islands $\left(8-9^{\circ} \mathrm{C}\right)$ and lowest off the Antarctic Peninsula $\left(\sim 2^{\circ} \mathrm{C}\right)$. Salinity only varied by 0.4 , with the highest values $(\sim 34.1)$ associated with the SAF on Transect 1 and the lowest values $(\sim 33.7-33.8)$ observed in the Antarctic Zone just north of the SACCF on both transects. Macronutrient concentrations increased towards Antarctica (Fig. 2b), with nitrate values between 16.5 and $27.0 \mu \mathrm{mol} \mathrm{kg}^{-1}$, phosphate values between 1.2 and $1.8 \mu \mathrm{mol} \mathrm{kg}^{-1}$ and silicic acid showing rapid changes associated with frontal positions and ranging from 1.4 to $50.9 \mu \mathrm{mol} \mathrm{kg}{ }^{-1}$. Such high nitrate and phosphate concentrations are unlikely to be limiting and the nitrate to phosphate ratio ranged from $14: 1$ to $16: 1$. The silicic acid to nitrate ratio was $2: 1$ close to Antarctica but fell to $1: 13$ north of the $\mathrm{PF}$, suggesting silicic acid limitation north of the $\mathrm{PF} . \mathrm{pH}_{\mathrm{T}}$ fluctuated by 0.08 units but did not exhibit a clear latitudinal trend (Fig. 2c). The highest $\mathrm{pH}_{\mathrm{T}}$ value (8.12) was found at station 24, between the two branches of the PF on Transect 1 , and the lowest value (8.04) was calculated for station 63, just north of the SACCF $(\mathrm{N})$ on Transect 2. Calcite saturation states $\left(\Omega_{\mathrm{C}}\right)$ ranged between 2.5 and 3.3 and exhibited an overall decrease towards Antarctica (Fig. 2c).

Euphotic zone depths $\left(Z_{\mathrm{eu}}, 39-100 \mathrm{~m}\right)$ were generally deeper than the MLD (15-65 m) across both transects (Fig. 2d), indicating that phytoplankton was not likely to be mixed down to depths where there was insufficient light. $Z_{\mathrm{eu}}$ was deepest in the Antarctic Zone, just north of the SACCF on both transects, and shallowest close to the continental shelves of Chile, Antarctica and the Falkland Islands. MLD did not exhibit a clear trend and was shallowest off the Chile and Falkland shelves and at a number of stations in the Subantarctic and Antarctic zones.

Surface Chl a concentrations were generally low $\left(<0.5 \mathrm{mg} \mathrm{m}^{-3}\right)$ across most of Drake Passage, with an average Chl $a$ of $0.26 \mathrm{mg} \mathrm{m}^{-3}$ (Fig. 2d). Higher Chl $a$ concentrations were observed in the Subantarctic and Continental
Table 1. Principal component (PC) analysis and Pearson product moment correlations between PC scores and environmental variables. ns indicates not significant.

\begin{tabular}{lrr}
\hline & PC-1 & PC-2 \\
& $(62.4 \%)$ & $(18.2 \%)$ \\
\hline Eigenvectors & & \\
\hline Temperature & -0.44 & -0.03 \\
Salinity & -0.33 & 0.29 \\
Nitrate & 0.43 & -0.07 \\
Phosphate & 0.43 & -0.04 \\
pH & -0.07 & 0.58 \\
$\Omega_{\mathrm{C}}$ & -0.43 & 0.20 \\
$\bar{E}_{\mathrm{MLD}}$ & -0.21 & -0.60 \\
PAR above surface & -0.32 & -0.40 \\
\hline Environmental variables $(p<0.01)$ & \\
\hline Temperature & -0.97 & $\mathrm{~ns}$ \\
Salinity & -0.75 & $\mathrm{~ns}$ \\
Nitrate & 0.95 & $\mathrm{~ns}$ \\
Phosphate & 0.95 & $\mathrm{~ns}$ \\
pH & $\mathrm{ns}$ & 0.70 \\
$\Omega_{\mathrm{C}}$ & -0.95 & $\mathrm{~ns}$ \\
$\bar{E}_{\text {MLD }}$ & -0.46 & -0.73 \\
PAR above surface & -0.72 & -0.49 \\
\hline
\end{tabular}

zones, with the maximum $\left(0.97 \mathrm{mg} \mathrm{m}^{-3}\right)$ associated with the SAF on Transect 2. The lowest Chl $a$ concentrations were observed in the Antarctic Zone, where surface concentrations were $<0.3 \mathrm{mg} \mathrm{m}^{-3}$.

Daily PAR above the sea surface $\left(\mathrm{PAR}_{\mathrm{above}}\right.$ surface $)$ ranged from 12 to $46 \mathrm{~mol} \mathrm{PAR} \mathrm{m}^{-2} \mathrm{~d}^{-1}$ (Fig. 2e). The highest

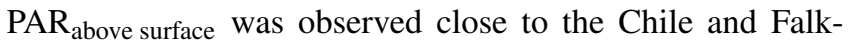
land shelves and decreased sharply towards the SAF. High values were also observed at some stations south of the PF and SAF. Low PAR above surface was observed close to Antarctica, especially on Transect 1 . Average mixed layer irradiance $\left(\bar{E}_{\mathrm{MLD}}\right)$ ranged between 2 and $12 \mathrm{~mol} \mathrm{PAR} \mathrm{m}^{-2} \mathrm{~d}^{-1}$ and gen-

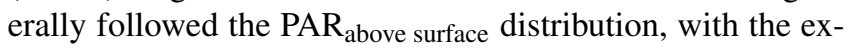
ception of a few stations where MLD was exceptionally shallow, resulting in relatively high $\bar{E}_{\text {MLD }}$ (Fig. 2e).

PCA of environmental variables (Fig. 3, Table 1) showed that the first principal component (PC-1) explained $62.4 \%$ of the variation in environmental variables and $\mathrm{PC}-1$ and $\mathrm{PC}-2$ explained $80.6 \%$. PC-1 was a linear combination of mainly temperature, phosphate, nitrate and $\Omega_{\mathrm{C}}$, with PC-1 and nutrients being anti-correlated to temperature and $\Omega_{\mathrm{C}}$ (Fig. 3, Table 1). PC-2 was the linear combination of mainly $\bar{E}_{\text {MLD }}$ and $\mathrm{pH}$, with PC-2 and $\mathrm{pH}$ being anti-correlated to $\bar{E}_{\mathrm{MLD}}$ (Fig. 3, Table 1). 


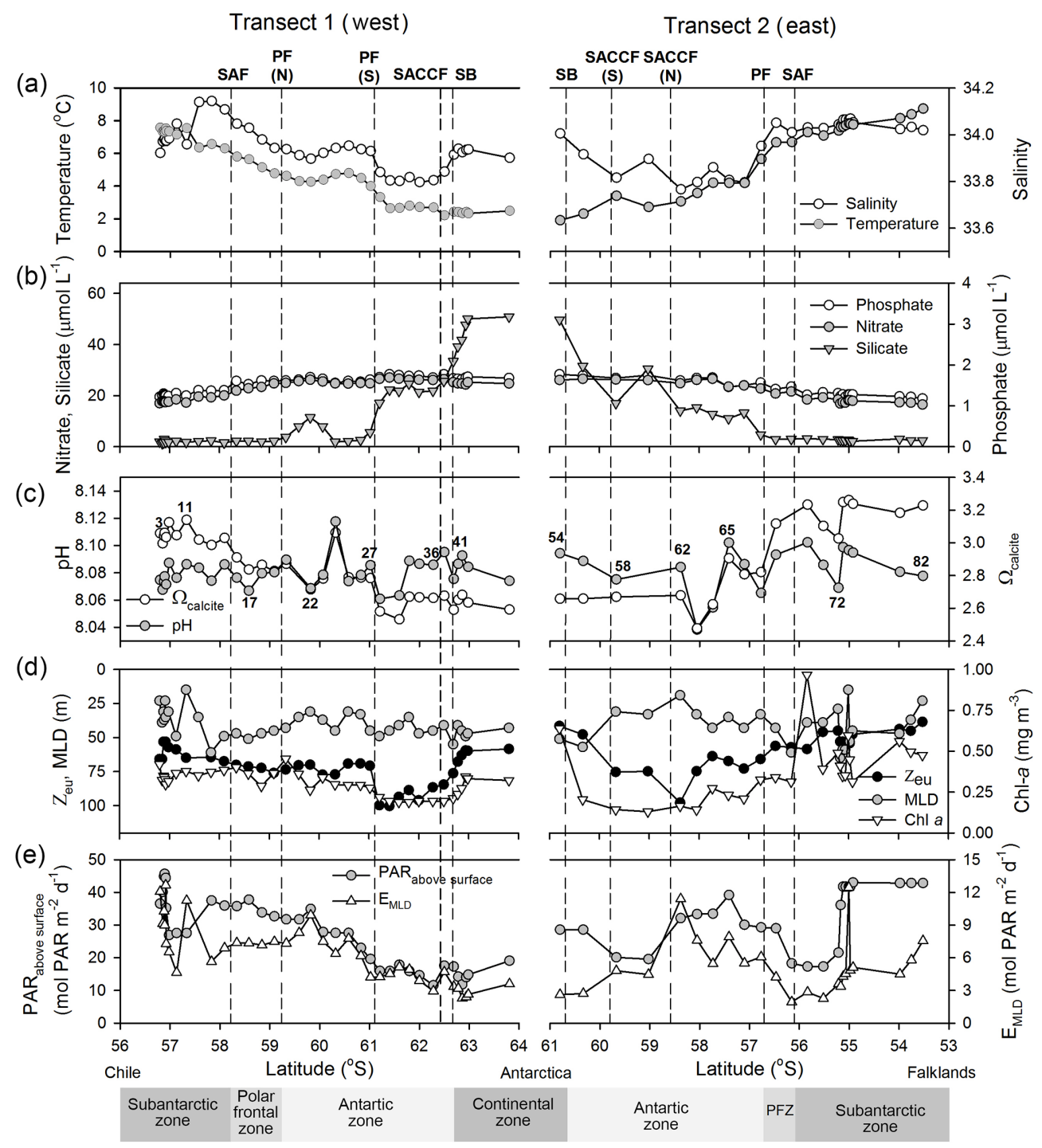

Figure 2. Surface distribution of physicochemical environmental variables along Transect 1 (left) and Transect 2 (right). (a) Temperature and salinity. (b) Nitrate, silicate and phosphate concentrations. (c) $\mathrm{pH}_{\mathrm{T}}$ and calcite saturation state $\left(\Omega_{\mathrm{C}}\right)$. (d) Euphotic zone depth $\left(Z_{\mathrm{eu}}\right)$, mixed layer depth (MLD) and Chl $a$. (e) Above-surface irradiance (PAR above surface) and mixed layer irradiance ( $\left.E_{\mathrm{MLD}}\right)$.

\subsection{Coccolithophores}

Fifteen coccolithophore taxa as coccospheres were identified in the samples across Drake Passage: Emiliania huxleyi, Acanthoica quattrospina, Calciopappus caudatus, Calcidiscus leptoporus, Gephyrocapsa ericsonii, G. muellerae, G. ornata, Ophiaster hydroideus, Pappomonas spp., Papposphaera spp., Rhabdosphaera xiphos, Syracosphaera dilatata, S. halldalii, S. molischii and Wigwamma antarctica. Emiliania huxleyi occurred across Drake Passage, comprising an average of $89 \%$ of the total community in surface samples, with a range from 50 to $100 \%$ (Fig. 4). At only three stations did the relative contribution of $E$. huxleyi fall below $80 \%$ of total cell numbers, with two of these stations south of the southern boundary in the Continental Zone (36 and 45).

Maximum coccolithophore abundance was associated with the SAF on both transects. Along Transect 1, E. huxleyi reached a maximum of $\sim 580$ cells $\mathrm{mL}^{-1}$ in the Polar Frontal Zone and 289 cells $\mathrm{mL}^{-1}$ between the two branches of the PF (Fig. 4). Along Transect 2, E. huxleyi abundance was generally $<200$ cells $\mathrm{mL}^{-1}$, but it peaked at 260 cells $\mathrm{mL}^{-1}$ at the SAF. In the Continental Zone near to Antarctica, it was only found in deeper samples $(>25 \mathrm{~m})$ at relatively low abundances $\left(<13\right.$ cells $\left.\mathrm{mL}^{-1}\right)$. Gephyrocapsa muellerae was characteristic of the Subantarctic Zone south of the Falkland Islands (Fig. 4), occasionally contributing $10-36 \%$ towards total abundance. Pappomonas sp. and W. antarctica 


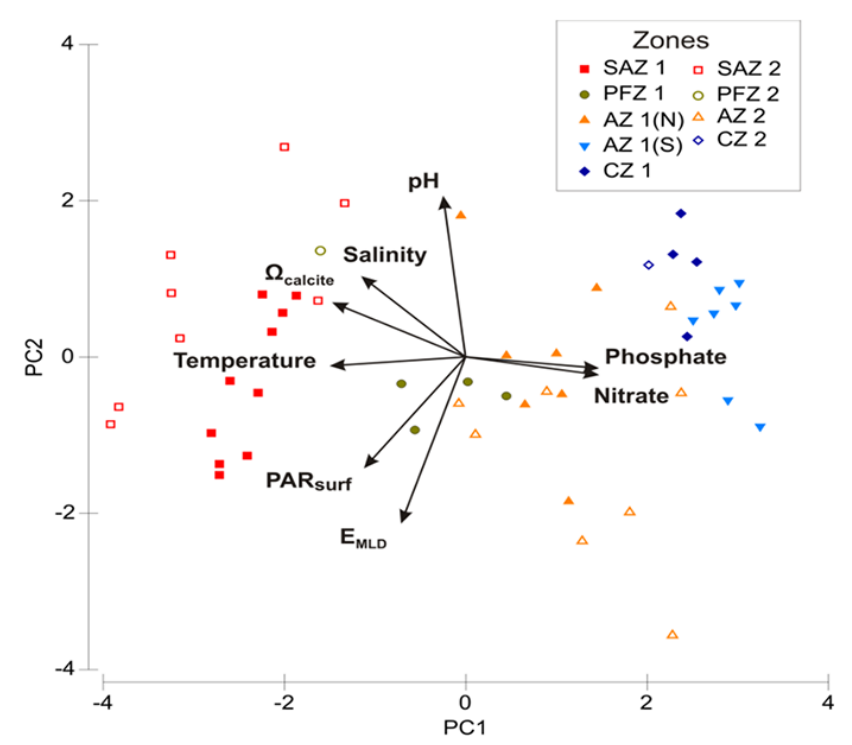

Figure 3. Ordination from principal component analysis of environmental variables. Environmental gradients are displayed as arrows indicating the direction of greatest change. Filled symbols represent samples from the different zones of Transect 1, and empty symbols samples are from Transect 2. SAZ is the Subantarctic zone, PFZ is the Polar Frontal Zone, AZ is the Antarctic Zone and CZ is the Continental Zone. $(\mathrm{N})$ and $(\mathrm{S})$ denote the northern and southern part of the AZ on Transect 1, as a result of the two branches of the Polar Front. Arrows and length of the arrows indicate the relative influence of each environmental variable on the PC axis; e.g. variables which align with PC-1 (temperature, phosphate, nitrate) strongly influence PC-1. Arrows which go in opposite directions indicate opposing relationships; e.g. temperature and nutrient concentrations are negatively related.

were found at low abundances in all regions and were the only coccolithophore species found in the surface waters of the Continental Zone. Acanthoica quattrospina and C. caudatus were found in the Subantarctic Zone of both transects and the Polar Frontal Zone on Transect 2. Finally, C. leptoporus was also observed in the Subantarctic Zone of both transects and additionally in the Antarctic Zone on Transect 1 (0.5-1.8 cells $\left.\mathrm{mL}^{-1}\right)$.

Due the high relative contribution of E. huxleyi to the total coccolithophore community ( $>80 \%$ and often up to a $100 \%$ ), surface trends in the distribution and abundance of total coccolithophores were very similar to that of $E$. huxleyi (Figs. 4 and 5). Diversity (species richness) generally declined with latitude (Fig. 5b), with the lowest number of species (1-2) present in the Antarctic and Continental zones of both transects. Coccolithophore cells were completely absent from several stations to the south of the southern boundary $(40,43,48$ and 54), although low numbers of detached coccoliths $\left(<0.01 \times 10^{3}\right.$ coccoliths $\left.^{-1} \mathrm{~mL}^{-1}\right)$ were present. Almost all detached coccoliths $(\sim 99 \%)$ came from E. huxleyi rather than from the other species present, with the aver- age detached coccolith: cell ratio $\sim 24: 1$. Coccosphere and detached coccolith distributions were very similar to each other (Fig. 5a; Spearman's $\rho=0.97, p<0.01$ ). Detached coccolith concentrations were maximal $\left(12 \times 10^{3} \mathrm{~mL}^{-1}\right)$ between the SAF and southern branch of the PF (PF-S) on Transect 1 , and the coccolith : cell ratio in this area was as high as $44: 1$. The maximum detached coccolith concentration on Transect 2 was associated with the SAF $\left(8.5 \times 10^{3} \mathrm{~mL}^{-1}\right)$, and the coccolith: cell ratio here was $33: 1$. At the majority of sampling stations coccolithophore abundance was maximal in surface waters (Charalampopoulou, 2011). However, at stations 18, 36, 62, 72 and 82 the maximum coccolithophore abundance was observed at $50 \mathrm{~m}$ depth (grey squares in Fig. 5a), although differences between surface and $50 \mathrm{~m}$ abundances were less than 60 cells $\mathrm{mL}^{-1}$.

\subsection{Community calcite production and cell-specific calcification}

Bulk CP by the coccolithophore community in surface waters ranged between 0.3 and $18.6 \mu \mathrm{mol} \mathrm{C} \mathrm{m}^{-3} \mathrm{~d}^{-1}$ (Fig. 5b). Relatively high $\mathrm{CP}$ was measured on either side of the SAF on Transect 1 (14.8-18.6 $\left.\mu \mathrm{mol} \mathrm{C} \mathrm{m}{ }^{-3} \mathrm{~d}^{-1}\right)$. Unfortunately, CP measurements were not made at the station of maximum coccolithophore abundance (Stn 16). On Transect 2, maximum CP was measured at the SAF and just south of the Falkland Islands $\left(\sim 10 \mu \mathrm{mol} \mathrm{C} \mathrm{m}^{-3} \mathrm{~d}^{-1}\right)$. Minimum $\mathrm{CP}$ was measured close to the Antarctic Peninsula in the Continental Zone $\left(<1 \mu \mathrm{mol} \mathrm{C} \mathrm{m} \mathrm{C}^{-3} \mathrm{~d}^{-1}\right)$. As with coccolithophore abundance, CP was generally maximal at the surface (data not shown; Charalampopoulou, 2011) apart from at stations 18, $36,62,72$ and 82 , where the maximum was observed at $50 \mathrm{~m}$ (grey squares in Fig. 5b). The difference between surface and $50 \mathrm{~m} \mathrm{CP}$ was less than $1 \mu \mathrm{mol} \mathrm{C} \mathrm{m}^{-3} \mathrm{~d}^{-1}$ at stations 18,36 , 62 and 82 , whereas the difference was $\sim 9 \mu \mathrm{mol} \mathrm{C} \mathrm{m}^{-3} \mathrm{~d}^{-1}$ at station 72 .

Cell-CF at the surface ranged from 0.01 to 0.16 pmol Ccell $^{-1} \mathrm{~d}^{-1}$ (Fig. 5c). The highest values of cell-CF $\left(0.13-0.16\right.$ pmol C cell $\left.^{-1} \mathrm{~d}^{-1}\right)$ were observed in the Subantarctic Zone on Transect 1, although lower values (0.04-0.06 pmol C cell $\left.{ }^{-1} \mathrm{~d}^{-1}\right)$ were also observed in this region. Cell-CF was generally less than $0.03 \mathrm{pmol} \mathrm{C}$ cell $^{-1} \mathrm{~d}^{-1}$ south of the SAF on Transect 1. The exception to this was at station 36, just north of the SACCF, where cell-CF was $\sim 2$ pmol C cell ${ }^{-1} \mathrm{~d}^{-1}$ (data not shown in Fig. 5c) and a very small community $\left(0.4\right.$ cells $\left.\mathrm{mL}^{-1}\right)$ was evenly split between E. huxleyi and Pappomonas spp. The $\mathrm{CP}$ at station 36 was also very low $\left(0.8 \mu \mathrm{mol} \mathrm{C} \mathrm{m}{ }^{-3} \mathrm{~d}^{-1}\right)$, and hence the cell-CF at this station should be viewed with caution (i.e. we ignore this station from our subsequent analysis).

On Transect 2 , maximum cell-CF $\left(0.10 \mathrm{pmol} \mathrm{Cell}^{-1}\right.$ $\mathrm{d}^{-1}$ ) was observed just north of the SACCF. North of station 62 , average cell-CF was $\sim 0.05 \mathrm{pmol} \mathrm{C}$ cell $^{-1} \mathrm{~d}^{-1}$, whereas values further south were lower. It was not possible to calculate cell-CF at station 54 because there was an absence of 




Figure 4. Surface water $(5 \mathrm{~m})$ abundance of major coccolithophore species along Transect 1 (left) and Transect 2 (right). Note the different scales of the abundance axes for different species.

detectable coccolithophore cells, despite a measurable, but very low, $\mathrm{CP}$ rate $\left(0.4 \mu \mathrm{mol} \mathrm{C} \mathrm{m}{ }^{-3} \mathrm{~d}^{-1}\right)$. Differences between surface and $50 \mathrm{~m}$ waters in terms of coccolithophore abundance and $\mathrm{CP}$ resulted in different cell-CF at $50 \mathrm{~m}$ (grey open squares in Fig. 5c) at stations 18, 36, 62, 72 and 82. However, none of these differences were significant relative to surface cell-CF (one-way ANOVA, $p<0.001$ ).

\subsection{E. huxleyi coccolith size, calcite content and production rates}

The overall mean coccolith DSL for E. huxleyi was $2.8 \mu \mathrm{m}$, while the median for each station ranged from 2.5 to $3.3 \mu \mathrm{m}$ and the full range was 1.8 to $5.5 \mu \mathrm{m}$ (Fig. 6a). Median DSLs were lowest in the Polar Frontal Zone on Transect 1 and in the Antarctic Zone on Transect 2. Maximum median DSLs for E. huxleyi were measured at stations located south of the Chile shelf (stations 3, 5, 8 and 11) and were significantly larger (pair-wise Turkey tests, $p<0.05$ ) than at all the other stations. Minimum median DSL was measured at station 62 $(2.5 \mu \mathrm{m})$. When E. huxleyi DSLs were converted to coccolith calcite content, following the equations of Young and Ziveri (2000), the overall mean was 0.010 pmol coccolith ${ }^{-1}$ and the median for each station ranged between 0.007 and 0.015 pmol coccolith $^{-1}$ (Fig. 6b), with the full range from 0.003 to 0.035 pmol coccolith $^{-1}$. Due to the method of estimating coccolith calcite content, and the complete dominance of morphotype B/C across Drake Passage, it showed an almost identical latitudinal pattern as DSL (Fig. 6a and b).

Division of cell-CF by estimates of coccolith calcite content gives an estimate of the rate of coccolith production per cell (Poulton et al., 2010, 2013). For communities across Drake Passage the overall mean coccolith production rate was 6 coccoliths cell ${ }^{-1} \mathrm{~d}^{-1}$ (Fig. 6c). Coccolith production rates were not calculated for stations 36 and 54 (see section above), despite the presence of detached coccoliths (Figs. 5a, 6a and b). Coccolith production rates were sig- 


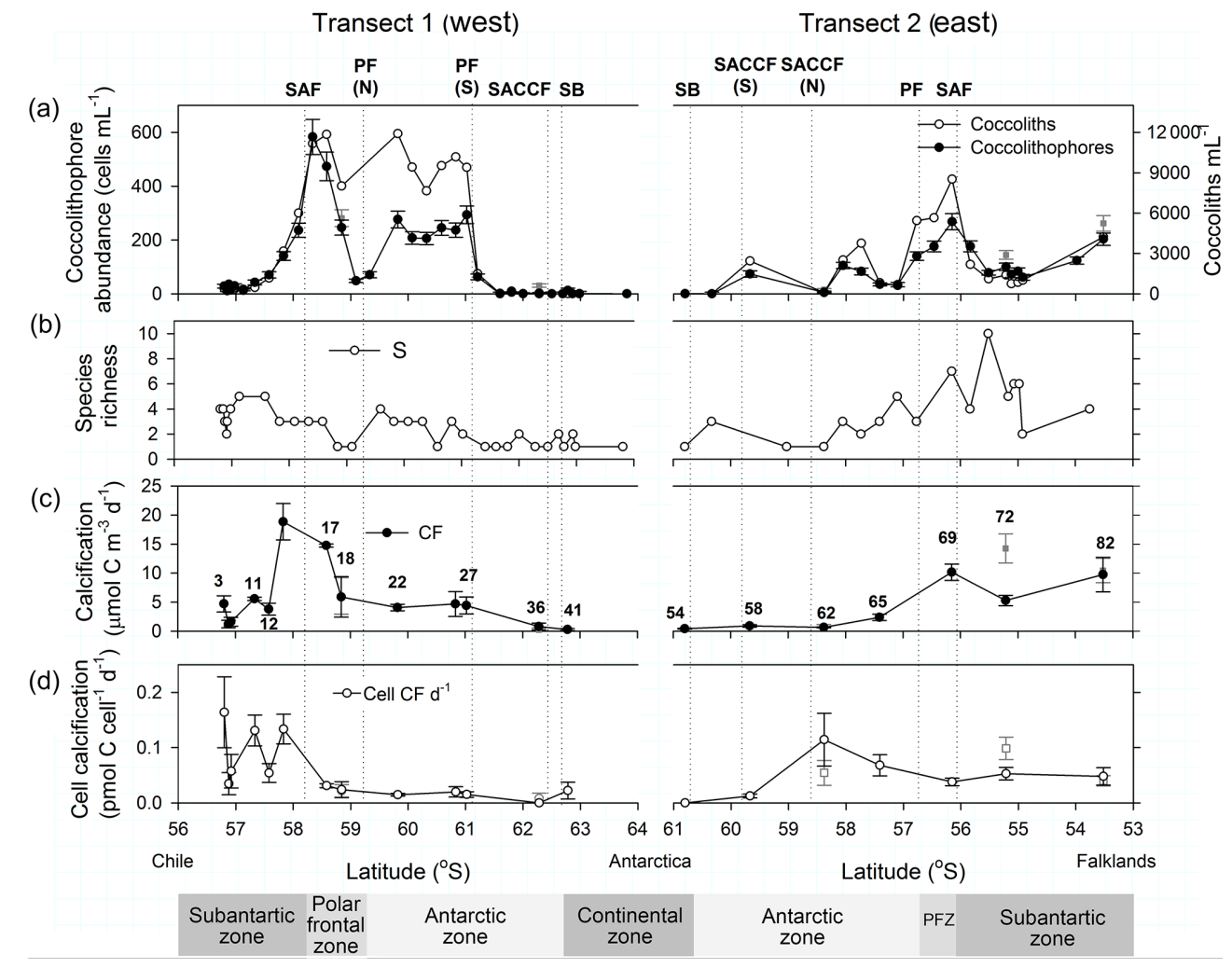

Figure 5. Surface water $(5 \mathrm{~m})$ distribution of coccolithophore variables along Transect 1 (left) and Transect 2 (right). (a) Total coccolithophore and detached coccolith abundance. (b) Species richness. (c) Community (bulk) calcification rates. (d) Cell-specific calcification rates. Grey filled and open squares show coccolithophore abundance, calcification and cell-specific calcification at $50 \mathrm{~m}$ depth, if the maximum was observed at this depth.

nificantly lower south of $59^{\circ} \mathrm{S}\left(<2\right.$ coccoliths cell ${ }^{-1} \mathrm{~d}^{-1}$ in Continental and Antarctic zones, stations 22-58) than in the Polar Frontal Zone, the Subantarctic Zone and at stations 62 and 65 in the northern part of the Antarctic Zone on Transect 2 (3-18 coccoliths cell $\left.{ }^{-1} \mathrm{~d}^{-1}\right)$ (Kruskal-Wallis, $p<0.001$; pairwise Tukey tests, $p<0.05)$. The highest coccolith production rates were observed at stations 14 and 62 (16-18 coccoliths cell $\left.{ }^{-1} \mathrm{~d}^{-1}\right)$.

\subsection{Relationships to environmental variables}

A multivariate analysis of variability in the coccolithophore community compared to that of environmental conditions (a BEST test) showed the strongest Spearman's rank correlation with a combination of temperature and $\bar{E}_{\mathrm{MLD}}(\rho=0.393$, $p<0.01)$. Spearman's rank correlations were also carried out between the principal components (PC-1 and PC-2), individual environmental variables, coccolithophore diversity (species number), CP, cell-CF, coccolith calcite content and coccolith production rates (Table 2). PC-1 was significantly correlated with coccolith calcite content, cell-CF and $\mathrm{CP}(p<0.01)$ as well as species number and coccolith production rates $(p<0.05)$. In contrast, correlations between PC-2 and characteristics of the coccolithophore community and cellular calcification were not statistically significant. Species richness (i.e. the number of species present) showed significant $(p<0.05)$ positive correlations with temperature, salinity, $\Omega_{\mathrm{C}}, \bar{E}_{\mathrm{MLD}}$ and $\mathrm{PAR}_{\text {above surface, }}$, and negative correlations with PC-1 and nutrient concentrations. Coccolith calcite content and CP were positivity correlated $(p<0.05)$ with temperature and $\Omega_{\mathrm{C}}$ and negatively correlated $(p<0.05)$ with PC-1 and nutrient concentrations. Cell-CF and coccolith production rates also showed a similar trend of statistically significant $(p<0.05)$ correlations, although they were additionally correlated with $\bar{E}_{\text {MLD }}$ and PAR above surface (Table 2). Generally, strong north-south gradients in environmental variables (temperature and $\Omega_{\mathrm{C}}$ decrease towards the south while nutrient concentrations increase) were also evident in coccolithophore diversity and cellular calcification across Drake Passage. 
(a)

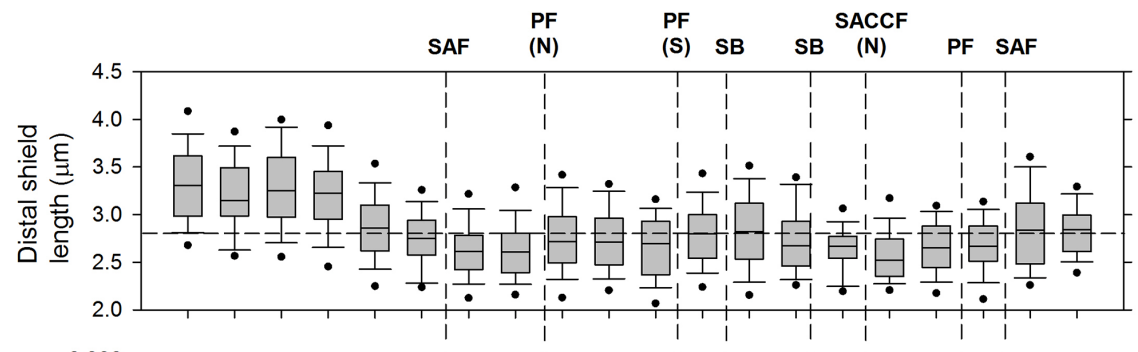

(b)

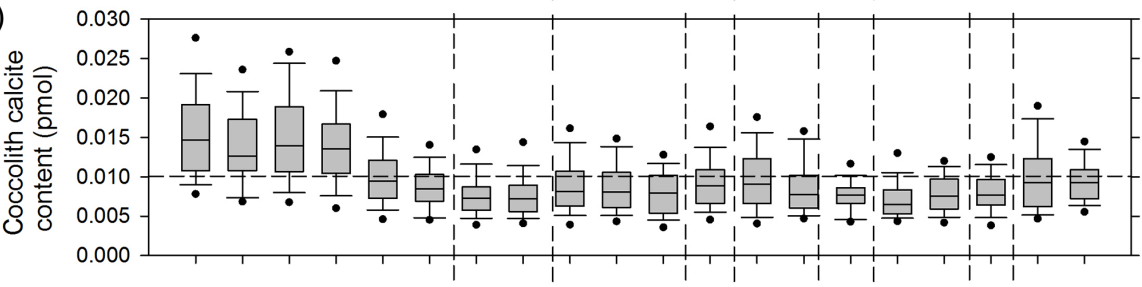

(c)

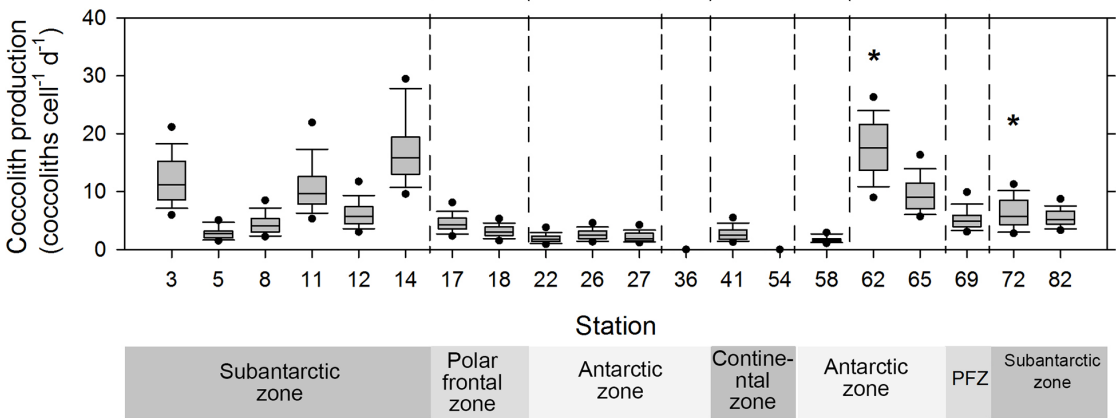

Figure 6. Box-and-whisker plots showing, for Emiliania huxleyi only, the size distribution of (a) coccolith distal shield length $(n=50)$, (b) coccolith calcite content and (c) surface coccolith production rates per cell, in each of the 20 stations. The solid line within boxes indicate the median, with 5th and 95th percentiles of the data bounding the box; horizontal bars indicates the minimum and maximum values and the points represent the 5th and 95th percentiles. The overall average for the whole dataset is indicated by the horizontal dashed lines across the panels. Asterisks indicate stations where maximum coccolithophore abundance and $\mathrm{CP}$ was measured at $50 \mathrm{~m}$ rather than at the surface.

Table 2. Spearman's rank correlations of species richness, calcification parameters and environmental variables. PC-1 is a combination of temperature, phosphate, nitrate and $\Omega_{\mathrm{C}}$ and PC-2 is a combination of $\bar{E}_{\mathrm{MLD}}$ and $\mathrm{pH}$. na indicates not applicable; ns is not significant.

\begin{tabular}{lrrrrr}
\hline $\begin{array}{l}\text { Environmental } \\
\text { variables }\end{array}$ & $\begin{array}{r}\text { Species } \\
\text { Richness }\end{array}$ & $\mathrm{CP}$ & Cell-CF & $\begin{array}{r}\text { Coccolith } \\
\text { calcite content }\end{array}$ & $\begin{array}{r}\text { Coccolith } \\
\text { production rate }\end{array}$ \\
\hline PC-1 & $-0.70^{\mathrm{a}}$ & $-0.64^{\mathrm{b}}$ & $-0.74^{\mathrm{b}}$ & $-0.57^{\mathrm{b}}$ & $-0.66^{\mathrm{a}}$ \\
PC-2 & $\mathrm{ns}$ & $\mathrm{ns}$ & $\mathrm{ns}$ & $\mathrm{ns}$ & $\mathrm{ns}$ \\
Temperature & $0.75^{\mathrm{a}}$ & $0.73^{\mathrm{b}}$ & $0.64^{\mathrm{b}}$ & $0.61^{\mathrm{b}}$ & $0.58^{\mathrm{b}}$ \\
Salinity & $0.64^{\mathrm{a}}$ & $0.57^{\mathrm{a}}$ & $\mathrm{ns}$ & $\mathrm{ns}$ & $\mathrm{ns}$ \\
Nitrate & $-0.63^{\mathrm{a}}$ & $-0.57^{\mathrm{a}}$ & $-0.75^{\mathrm{b}}$ & $-0.63^{\mathrm{b}}$ & $-0.67^{\mathrm{b}}$ \\
Phosphate & $-0.64^{\mathrm{a}}$ & $-0.56^{\mathrm{a}}$ & $-0.80^{\mathrm{b}}$ & $-0.60^{\mathrm{b}}$ & $-0.72^{\mathrm{b}}$ \\
$\mathrm{pH}$ & $\mathrm{ns}$ & $\mathrm{ns}$ & $\mathrm{ns}$ & $\mathrm{ns}$ & $\mathrm{ns}$ \\
$\Omega_{\mathrm{C}}$ & $0.70^{\mathrm{a}}$ & $0.67^{\mathrm{b}}$ & $0.70^{\mathrm{b}}$ & $0.57^{\mathrm{a}}$ & $0.63^{\mathrm{b}}$ \\
$\bar{E}_{\text {MLD }}$ & $0.29^{\mathrm{a}}$ & $\mathrm{ns}$ & $0.62^{\mathrm{b}}$ & $\mathrm{ns}$ & $0.61^{\mathrm{b}}$ \\
PAR & $0.40^{\mathrm{a}}$ & $\mathrm{ns}$ & $0.50^{\mathrm{a}}$ & $\mathrm{ns}$ & $0.49^{\mathrm{a}}$ \\
Temperature,, $\bar{E}_{\text {MLD }}$ & $\mathrm{na}$ & $\mathrm{na}$ & $\mathrm{na}$ & $\mathrm{na}$ & $\mathrm{na}$ \\
\hline
\end{tabular}

${ }^{\mathrm{a}} p<0.05 .{ }^{\mathrm{b}} p<0.01$. 


\section{Discussion}

\subsection{Coccolithophore distribution in the Southern Ocean}

In this study, the surface waters across Drake Passage were sampled along two latitudinal transects to assess coccolithophore abundance and species distribution. The total coccolithophore abundances that we observed (up to $\sim 600$ cells $\mathrm{mL}^{-1}$ ) agree with previous observations of maximum abundances of between 200 and 500 cells $\mathrm{mL}^{-1}$ in the Atlantic, Pacific, Indian and Australian sectors of the Southern Ocean (Cubillos et al., 2007; Eynaud et al., 1999; Findlay and Giraudeau, 2000; Gravalosa et al., 2008; Mohan et al., 2008; Hinz et al., 2012; Saavedra-Pellitero et al., 2014; Malinverno et al., 2015; Balch et al., 2016). A previous study across Drake Passage (December, 2006), coinciding with the eastern transect (Transect 2), reported similar abundances of up to 600 cells $\mathrm{mL}^{-1}$ (Holligan et al., 2010). Maxima in coccolithophore abundance were associated with oceanic fronts and particularly with the SAF and PF, as observed in other studies (Eynaud et al., 1999; Gravalosa et al., 2008; Holligan et al., 2010; Saavedra-Pellitero et al., 2014; Malinverno et al., 2015; Balch et al., 2016). These abundance maxima may be related to high primary productivity due to the dynamics of frontal systems and increased nutrient (presumably dissolved iron) availability (Eynaud et al., 1999; Gravalosa et al., 2008; Balch et al., 2016).

The southern limit for coccolithophores was once thought to be the PF (Winter et al., 1999); however, low numbers of coccolithophores have more recently been observed as far south as the SACCF (see review by Malinverno et al., 2015). In the Southern Ocean, temperature has been suggested to control coccolithophore distribution, as coccolithophore barren waters are typically less than $2{ }^{\circ} \mathrm{C}$ (Holligan et al., 2010). In our study, no E. huxleyi cells were found south of the SACCF in surface waters, although detached coccoliths were still present $\left(<20\right.$ coccoliths $\left.\mathrm{mL}^{-1}\right)$ and low numbers of E. huxleyi $\left(<13\right.$ cells $\left.\mathrm{mL}^{-1}\right)$ were observed in deeper waters $(>25 \mathrm{~m})$. Low abundances $\left(1-2\right.$ cells $\left.\mathrm{mL}^{-1}\right)$ of $W$. antarctica were also found in samples south of the SACCF and at the southern boundary of the ACC. However, during our study surface water temperatures were always above $2{ }^{\circ} \mathrm{C}$, even at the most southerly stations.

A number of previous studies have reported a succession of E. huxleyi morphotypes with increasing latitude in the Southern Ocean, with morphotype A being replaced by morphotype B/C towards Antarctica in the Australian, Pacific and Indian sectors (Findlay and Giraudeau, 2000; Cubillos et al., 2007; Mohan et al., 2008; Cook et al., 2011; SaavedraPellitero et al., 2014; Malinverno et al., 2015). Across Drake Passage we only observed morphotype $\mathrm{B} / \mathrm{C}$, regardless of latitude. Sea-surface temperatures were always less than $10^{\circ} \mathrm{C}$ across Drake Passage, conditions which seem to favour dominance of the B/C morphotype (Findlay and Giraudeau, 2000;
Mohan et al., 2008; Holligan et al., 2010; Poulton et al., 2011; Cook et al., 2011; Saavedra-Pellitero et al., 2014). In the Australian sector of the Southern Ocean, morphotype A occurs as far south as the Subantarctic Zone (Cubillos et al., 2007), while in the Atlantic sector it has only been observed in warm, nutrient-poor waters north of the Patagonian Shelf so far (Poulton et al., 2011).

Apart from E. huxleyi, other coccolithophore species are scarce in the Southern Ocean, especially polewards of the Subantarctic Zone (Eynaud et al., 1999; Mohan et al., 2008; Holligan et al., 2010; Saavedra-Pellitero et al., 2014). In this study, G. muellerae was found at moderate abundances (up to $36 \%$ of total numbers) south of the Falklands and close to the SAF. These observations match those of Holligan et al. (2010) in the same area and suggest that G. muellerae is a characteristic species in the region south of the Falkland Islands. Gephyrocapsa muellerae, A. quattrospina, $C$. caudatus and $C$. leptoporus were also more abundant north of the Polar Front (Fig. 4), which confirms their preference for subpolar regions in both the Southern Ocean (Eynaud et al., 1999; Findlay and Giraudeau, 2000; Saavedra-Pellitero et al., 2014; Malinverno et al., 2015) and the Northern Hemisphere (Samtleben et al., 1995; Baumann et al., 2000). Pappomonas spp. and $W$. antarctica, with their small cells and low-calcite-containing coccoliths (Young et al., 2003), were ubiquitous and the only species recorded in surface waters of the Continental Zone close to Antarctica, albeit at low cell densities. Species of the family Papposphaeraceae (including Pappomonas and Papposphaera spp.) are characteristic of Arctic waters (Thomsen, 1981; Charalampopoulou et al., 2011) and, together with Wigwamma spp., they are also characteristic of the Australian and Pacific Antarctic zones (Findlay and Giraudeau, 2000; Saavedra-Pellitero et al., 2014).

\subsection{A polewards decrease in calcification?}

A conspicuous feature of the results as a whole is the southwards decline in coccolithophores (abundance, diversity) and calcite production (Fig. 5). Most parameters have higher average values closer to South America and lower average values closer towards Antarctica. The prevalence of this trend was examined further by splitting the data from the intensively studied stations (red circles in Fig. 1) into two groups, a more northerly one consisting of data north of the polar front (north of $\mathrm{PF}(\mathrm{S})$ on the western transect) and a more southerly one consisting of data south of the polar front (stations 36 to 55). One-tailed, two-sample $t$ tests (unpaired, unequal sample sizes and unequal variances) support the hypothesis that values were, on average, significantly higher to the north (i.e. rejected the null hypothesis that values to the south were higher than or equal to values to the north) for most of the parameters shown in Fig. 5 (coccosphere concentration, $p<0.001$; coccolith concentration, $p<0.01$; calcite production rate, $p<0.001$; cellular calcification rate, $H_{0}$ not rejected). Coccolithophore and coccolith concentrations, 
as well as community calcite production, were all found to be lower on average to the south. However, the hypothesis of significantly lower values to the south was not supported for the rates of cell-CF or coccolith production. Some values of these parameters are high in the Antarctic Zone on the eastern transect (Figs. 5c and 6c), where non-negligible calcite production (Fig. 5b) were measured at stations 62 and 65 in waters containing very few cells (Fig. 5a). These surprising higher values could potentially be explained by either (i) coccolithophores calcifying at relatively normal rates to the south (see below) or (ii) artefacts in the calculations due to uncertainties from low cell number counts. However, calculations of propagated errors (shown in Fig. 5c) suggest that such errors only explain a small proportion of the rates of cell-CF and coccolith production at stations 62 and 65 .

The absence from high-latitude polar waters was, until recently, a long-held paradigm in coccolithophore ecology (McIntyre and Bé, 1967; Winter and Siesser, 1994), although more recent studies have found a polewards expansion in their range (e.g. Holligan et al., 2010; Winter et al., 2014; Malinverno et al., 2015). When combined with the polewards decrease in the $\mathrm{CaCO}_{3}$ saturation state of seawater (Orr et al., 2005), this led to the suggestion (e.g. Cubillos et al., 2007; Beaufort et al., 2011) that coccolithophores may struggle in polar waters because of difficulties in calcifying in the low $\mathrm{CaCO}_{3}$ saturation conditions. The data presented here are, however, not consistent with this hypothesis. If low saturation states inhibit calcification, and this is a dominant reason for low coccolithophore abundance where it occurs, then we would expect to see low abundances in the same places as we see low cell-CF. This is true in some areas; for instance, both parameters have very low values towards the southern ends of both transects (e.g. stations 41 and 58; Fig. 5). However, there are also areas where coccolithophores are scarce but cell-CF are high (for instance stations 62 and 65; Fig. 5) and, conversely, where coccolithophores are relatively numerous but cell-CF is low (for instance stations 22 and 27; Fig. 5). Overall these two parameters were in fact anti-correlated in surface waters of the study area (Spearman $\rho=-0.46, p<0.05)$, suggesting that difficulty in calcifying may not be the main reason for the very low coccolithophore numbers in some parts of the Southern Ocean. Rather, variability in physiological factors (e.g. light availability), which influence intrinsic growth rates, and mortality factors (e.g. grazing rates) may be more influential on coccolithophore cell numbers (Poulton et al., 2010). Species-specific differences in cellular calcite content and variability in intrinsic growth rates will also influence trends in cell-CF (Poulton et al., 2010; Charalampopoulou et al., 2011).

\subsection{Cellular calcification across Drake Passage}

This study presents the most southerly direct measurements of calcification rates currently available. Emiliania huxleyi morphotype $\mathrm{B} / \mathrm{C}$ represented over $80 \%$ of total cell numbers (and up to a $100 \%$ in many cases) across Drake Passage, with other species (A. quattrospina, C. leptoporus, G. muellerae) contributing relatively little to the total community. Hence, we propose that the calcification rates presented in this study are characteristic of E. huxleyi across Drake Passage. CP was low $\left(<20 \mu \mathrm{mol} \mathrm{C} \mathrm{m}{ }^{-3} \mathrm{~d}^{-1}\right)$ compared to subarctic regions during both bloom $\left(50-1500 \mu \mathrm{mol} \mathrm{C} \mathrm{m}^{-3} \mathrm{~d}^{-1}\right.$; Fernandez et al., 1993; Poulton et al., 2013, 2014) and non-bloom conditions (50-250 $\mu \mathrm{mol} \mathrm{C} \mathrm{m}^{-3} \mathrm{~d}^{-1}$; Poulton et al., 2010), but more similar to measurements from the (sub)tropics (10$50 \mu \mathrm{mol} \mathrm{C} \mathrm{m}{ }^{-3} \mathrm{~d}^{-1}$; Poulton et al., 2007; Balch et al., 2011). The ratio of CP to PP for the bulk phytoplankton community (data not shown) was also similar to (sub)tropical communities (0.001-0.069; Poulton et al., 2007) and lower than those generally in the Great Calcite Belt (Balch et al., 2016), highlighting that coccolithophores contributed only a small fraction $(<1 \%)$ to upper ocean carbon fixation across Drake Passage (see Charalampopoulou, 2011).

The range of cell-CF was also lower (0.01-

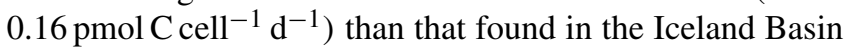
during non-bloom conditions $\left(0.25-0.75 \mathrm{pmol} \mathrm{C}\right.$ cell $^{-1} \mathrm{~d}^{-1}$; Poulton et al., 2010) or in monospecific E. huxleyi cultures (0.2-0.8 pmol Ceell ${ }^{-1} \mathrm{~d}^{-1}$; Balch et al., 1996). However, cell-CF was more similar to measurements from the Patagonian Shelf bloom $\left(0.05-0.6 \mathrm{pmolC} \mathrm{Cell}^{-1} \mathrm{~d}^{-1}\right.$; Poulton et al., 2013). In the Iceland Basin, E. huxleyi morphotype A dominates, whereas on the Patagonian Shelf and across Drake Passage morphotype B/C dominates. These levels of cell-CF translate into coccolith production rates of $0.1-1.2$ coccoliths cell ${ }^{-1} \mathrm{~h}^{-1} \quad\left(2-18\right.$ coccoliths cell ${ }^{-1} \mathrm{~d}^{-1}$, assuming a $15 \mathrm{~h}$ light period), using the mean coccolith calcite values estimated for morphotype $\mathrm{B} / \mathrm{C}$ at each station $\left(0.007-0.015 \mathrm{pmol} \mathrm{C}\right.$ cocolith $\left.^{-1}\right)$. These are within the range reported for morphotype $\mathrm{A}$ in culture (0-3 coccoliths cell ${ }^{-1} \mathrm{~h}^{-1}$; Balch et al., 1996) and field studies in the Iceland Basin $\left(0.4-1.8\right.$ coccoliths cell ${ }^{-1} \mathrm{~h}^{-1}$; Fernandez et al., 1993; Poulton et al., 2010). Measurements from the Patagonian Shelf bloom, composed exclusively of $E$. huxleyi morphotype $\mathrm{B} / \mathrm{C}$, gave coccolith production rates of $0.1-3.3$ coccoliths cell ${ }^{-1} \mathrm{~h}^{-1}$ (Poulton et al., 2013). Hence, even though cell-CF rates for morphotype B/C appear to be low compared to morphotype A, the rate at which individual coccoliths were produced is generally similar between $E$. huxleyi morphotypes when differences in coccolith calcite content are taken into account.

Although there is general similarity in the range of coccolith production rates between subpolar environments, the calculated rates along the two transects (Fig. 6c) show a general trend across Drake Passage of lower coccolith production close to Antarctica in the Continental Zone than further north (Fig. 6c) (although stations 62 and 65 are, as noted above, an exception to the north-south trend). Hence, indices of cellular calcification (including cell-specific calcification, calcite content per coccolith and coccolith production rates) all show reductions south of the Subantarctic Front in Drake Passage 
and with increasing proximity to the Antarctic Peninsula. It is important to clarify that the decrease in cell-CF is linked to reductions in the rate at which each cell produces coccoliths rather than strong reductions in the size or calcite content of individual coccoliths: coccolith calcite is a poor indicator of coccolith production rates or levels of cellular calcification. Apart from those close to Antarctica, E. huxleyi populations in the Southern Ocean are producing coccoliths at similar rates to populations in other environments.

\subsection{Coccolith morphometrics across Drake Passage}

In this study, the overall mean DSL of E. huxleyi morphotype B/C detached coccoliths $(2.8 \mu \mathrm{m}$; see Fig. 6) was at the lower end of the range reported in cultured $\mathrm{B} / \mathrm{C}$ strains (range 2.65-4.80 $\mu \mathrm{m}$; Cook et al., 2011) and lower than the average seen on the Patagonian Shelf $(3.25 \pm 0.40 \mu \mathrm{m}$; Poulton et al., 2011). A strong latitudinal trend was observed in DSL of morphotype B/C coccoliths, from the Chile shelf (median $>3.1 \mu \mathrm{m}$ ) to smaller ones further south (median $<2.9 \mu \mathrm{m}$ ). A north-south trend was also observed from "over-calcified to weakly calcified E. huxleyi morphotypes" in the Australian and Indian sectors of the Southern Ocean (Findlay and Giraudeau, 2000; Cubillos et al., 2007; Mohan et al., 2008). However, a similar trend was not observed south of the Falklands (station 82; Fig. 6), where average DSL was also $<2.9 \mu \mathrm{m}$, even though environmental conditions were similar to those off Chile.

Coccolith calcite content derived from our DSL measurements (mean $0.010 \mathrm{pmol} \mathrm{C}$ coccolith $^{-1}$ ) was lower than estimates for the $\mathrm{B} / \mathrm{C}$ morphotype based on a regression of total coccoliths to discrete calcite measurements (0.020 pmol C coccolith $^{-1}$; Holligan et al., 2010), and from DSL measurements of detached coccoliths on the Patagonian Shelf $\left(0.015 \mathrm{pmolC}_{\mathrm{Coc} \text { colith }}^{-1}\right.$; Poulton et al., 2011). In our study, coccolith calcite was between 0.013 and 0.015 pmol C coccolith $^{-1}$ off southern Chile

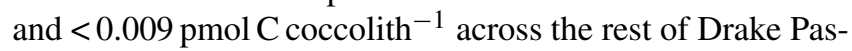
sage. The wide range of DSL observed across Drake Passage $(1.8-4.4 \mu \mathrm{m})$ also highlights the natural variability found within populations of E. huxleyi (Poulton et al., 2011; Young et al., 2014).

\subsection{Environmental drivers of coccolithophores and calcification}

The combination of environmental variables best able to explain variability in coccolithophore community composition across Drake Passage were temperature and mixed layer irradiance $(\rho=0.393, p<0.05)$. These were also the two variables best correlated with the first and second principal components (PC-1 and PC-2) in the PCA of environmental factors. Combined PC- 1 and PC-2 explained $80 \%$ of the variation in the environmental data. Mohan et al. (2008) also found that coccolithophore distribution south of Madagas- car towards Antarctica was controlled by temperature and light, with higher diversity in warmer and higher irradiance conditions, and high abundances of monospecific E. huxleyi assemblages corresponding to high nitrate concentrations in the Subantarctic Zone. Across Drake Passage, macronutrient concentrations were not limiting, while $\bar{E}_{\text {MLD }}$ was less than $3 \mathrm{molPAR} \mathrm{m}^{-2} \mathrm{~d}^{-1}$ across the Continental Zone and just north of the SAF on Transect 2, a threshold below which light is potentially limiting for Southern Ocean phytoplankton (Venables and Moore, 2010). This suggests that coccolithophore distribution and abundance is controlled primarily by temperature and light rather than nutrient concentrations or carbon chemistry.

Calcification parameters (coccolith calcite content, coccolith production rates, cell-CF and $\mathrm{CP}$ ) were all negatively correlated with PC-1 and were higher in warm, lower nutrient, higher $\Omega_{\mathrm{C}}$ conditions; they all decreased towards Antarctica, as the individual correlations show (Table 2). Additionally, coccolith production rates and cell-CF were positively correlated with $\bar{E}_{\mathrm{MLD}}$ and both of these were higher at stations where both temperature and $\bar{E}_{\mathrm{MLD}}$ were relatively high (mean values of $6.6^{\circ} \mathrm{C}$ and $7.4 \mathrm{~mol} \mathrm{PAR} \mathrm{m}^{-2} \mathrm{~d}^{-1}$, respectively). The positive correlation of coccolith production rates and cell-CF with $\bar{E}_{\mathrm{MLD}}$ is not surprising as these are strongly light dependent in E. huxleyi cultures (Linschooten et al., 1991; Zondervan et al., 2002) and in field populations where both total and cell-CF rates decrease with depth (Fernandez et al., 1993; Poulton et al., 2010, 2014).

The correlation of calcification indices with phosphate and nitrate is most likely the result of the strong anticorrelations that exist between nutrient concentrations and temperature $\left(r^{2}=0.88\right.$ and 0.89 , nitrate and phosphate respectively; $n=50, p<0.01$ ) across Drake Passage. A similar inter-correlation may also explain the observed trend of decreasing calcite production with decreasing $\Omega_{\mathrm{C}}$ across Drake Passage, as this variable is also strongly correlated with temperature $\left(r^{2}=0.86, n=50, p<0.01\right)$. A strong trend in cellular calcification (cell-CF, coccolith production) with $\Omega_{\mathrm{C}}$ is in general agreement with suggestions of carbonate chemistry as a strong driver of pelagic calcification (Cubillos et al., 2007; Beaufort et al., 2011). However, as can be seen across Drake Passage, $\Omega_{\mathrm{C}}$ co-varies with all the other growthdependent variables (i.e. nutrients, irradiance and temperature) and the effect of one over any of the others is difficult to distinguish. This highlights how environmental gradients in the ocean can work in tandem to control coccolithophore growth and calcification: organisms are not usually faced with only one eco-physiological driver changing at a time; the environment is multivariate.

The one growth-dependent factor lacking from our study, especially relevant to the Southern Ocean, is iron availability. Notably, within the factors included only a limited degree of the variability in coccolithophore species distribution $(\rho=0.393)$ was explained and only moderate correlations between calcification and environmental factors were found 
(Table 2). Presently, the influence of iron on coccolithophore distribution and physiology is unclear and the literature is conflicting. Brand (1991) found E. huxleyi to have relatively low iron requirements compared with diatoms (Zondervan et al., 2007), with some iron addition experiments showing no response (Lam et al., 2001; Assmy et al., 2007). In contrast, other studies have shown increased CP (Crawford et al., 2003) and cell abundances (Nielsdóttir et al., 2009) and proposed iron as a potentially important growth-limiting factor to subpolar northern hemispheric coccolithophore communities (Poulton et al., 2010). More recently, iron has been shown to control the distribution and growth of coccolithophores in the Great Calcite Belt (Balch et al., 2016) in the Southern Hemisphere. Furthermore, iron supplied through sedimentary sources has also been suggested to influence the formation of the Patagonian Shelf coccolithophore bloom, which occurs in cold, macronutrient-rich water originating north of the SAF (Garcia et al., 2008; Poulton et al., 2013; Balch et al., 2014, 2016). Clearly more work is required to examine the role of iron on Southern Ocean coccolithophore biogeography and calcification, as well as its potential influence on coccolithophore blooms and coccolithophore growth in mixed communities.

\subsection{Global change effects on coccolithophores in the Southern Ocean}

Future changes in the Southern Ocean are expected to include higher temperatures and stronger stratification, leading to higher $\bar{E}_{\mathrm{MLD}}$ but lower nutrient availability (Boyd et al., 2008), while at the same time $\Omega_{\mathrm{C}}$ is predicted to decrease (Hauri et al., 2015). Our statistical analysis suggests that changes to temperature and/or $\Omega_{\mathrm{C}}$ both affect coccolithophores, but we were not able to determine robustly which out of these is likely to be most critical. In addition, higher $\bar{E}_{\mathrm{MLD}}$ is predicted to favour coccolithophores and more recently increased $p \mathrm{CO}_{2}$ has been suggested to favour the polewards expansion of $E$. huxleyi (Winter et al., 2014) and increases in coccolithophores in the North Atlantic (Rivero-Calle et al., 2015). Across Drake Passage, increases in temperature and stratification could therefore potentially facilitate a polewards expansion of the range of E. huxleyi, which would in turn reduce the extent of the low-calcite production area around Antarctica. Such a poleward migration of E. huxleyi might lead to a range expansion of the $\mathrm{B} / \mathrm{C}$ morphotype, the low-calcite ecotype found in the Southern Ocean (this study; Cook et al., 2011, 2013; Poulton et al., 2011, 2013).

Although coccolithophore cell densities may increase, with coccolith production rates fairly similar to North Atlantic populations, if $\mathrm{B} / \mathrm{C}$ remains the dominant morphotype then the resulting calcification rates will still be relatively low due to the low cellular calcite. Such a migration of E. huxleyi has already been observed in the Australian sector of the Southern Ocean (Cubillos et al., 2007; Winter et al., 2014), as well as in the Bering and Barents seas (Merico et al., 2003; Smyth et al., 2004). Limited sensitivity to $\mathrm{CO}_{2}$ has also been observed in several strains of E. huxleyi (Langer et al., 2009, $2011)$ and at low growth irradiances $\left(<5 \mathrm{~mol} \mathrm{PAR} \mathrm{m}^{-2} \mathrm{~d}^{-1}\right.$; Zondervan et al., 2002). In the Southern Ocean, $\bar{E}_{\mathrm{MLD}}$ is generally low (mean $\sim 5 \mathrm{molPAR} \mathrm{m}^{-2} \mathrm{~d}^{-1}$ in this study) and short-term predicted changes are unlikely to exceed background variability (Boyd et al., 2008). Hence, it is also feasible that any reductions in calcification due to ocean acidification may be minimal or be opposed by the effects of increased sea-surface temperatures and light availability. Furthermore, if increased $\mathrm{CO}_{2}$ availability for E. huxleyi also favours growth and range expansions of this species (Winter et al., 2014; Rivero-Calle et al., 2015), then this will also compound the potential effects of changes in the environment.

\subsection{Summary}

The coccolithophore community across Drake Passage was dominated by the low coccolith calcite $\mathrm{B} / \mathrm{C}$ morphotype of E. huxleyi. Most coccolithophore and calcification indices declined towards Antarctica, including both bulk and individual rates of calcification per cell. Despite this, coccolithophore abundance and individual calcification rate per cell were anti-correlated. Taken as a whole, measures of coccolithophore abundance and calcification across Drake Passage were rather low compared to elsewhere in the global ocean, although cellular rates of coccolith production $(0.1-$ 1.2 coccoliths cell ${ }^{-1} \mathrm{~h}^{-1}$ ) were very similar to values in the Iceland Basin (Poulton et al., 2010) and on the Patagonian Shelf (Poulton et al., 2013), except at the southern end of the transects where they declined to very low values $\left(<0.3\right.$ coccoliths cell $\left.{ }^{-1} \mathrm{~h}^{-1}\right)$. However, due to the low coccolith calcite content characteristic of morphotype B/C, community CP $\left(<20 \mu \mathrm{mol} \mathrm{C} \mathrm{m}{ }^{-3} \mathrm{~d}^{-1}\right)$ was more similar to rates in (sub)tropical waters than in the Iceland Basin (Poulton et al., 2007, 2010; Balch et al., 2011).

Temperature and irradiance were found to be best able to explain variation in coccolithophore species distribution and abundance across Drake Passage. Similarly, calcification parameters correlated with the strong latitudinal gradients in temperature, nutrients and $\Omega_{\mathrm{C}}$, while cell-specific calcification and coccolith production rates also correlated with $\bar{E}_{\mathrm{MLD}}$. However, temperature, nutrients and $\Omega_{\mathrm{C}}$ were all strongly inter-related across Drake Passage, and so it was not possible to robustly separate their individual influence on the calcification parameters. It is therefore difficult to be sure how coccolithophores and calcite production in the Southern Ocean will respond to global change as a whole, because of the contrasting predicted trends in water temperature, nutrients and $\Omega_{\mathrm{C}}$. 


\section{Data availability}

Data included in the paper are available from various sources: via the PANGAEA data repository as Tyrrell and Charalampopoulou (2009) for the measurements of coccolithophore size, abundance and calcification, alongside the hydrographic measurements and nutrient data; via the CDIAC data repository as Bakker et al. (2013) for the carbon dioxide, hydrographic and chemical data; or via the BODC data repository (www.bodc.ac.uk) as BODC document 225553 for the dissolved inorganic carbon and total alkalinity measurements.

Acknowledgements. We would like to thank the officers and crew of the RRS James Clark Ross, the scientists and Principal Scientific Officer, Elaine McDonagh, of JC031. Furthermore, we would like to thank Chris Daniels for reading and commenting on a previous draft. The authors would also like to acknowledge the support of Oceans 2025 and National Capability funding which supports the Drake Passage Sustained Observation project. Anastasia Charalampopoulou was supported by a University of Southampton $\mathrm{PhD}$ studentship, with her participation in the JC031 supported by Oceans 2025 funding. Alex J. Poulton was supported by a UK Natural Environmental Research Council (NERC) postdoctoral fellowship (NE/F015054/1). Dorothee C. E. Bakker was supported by a NERC research grant (NE/F01242X/1). Anastasia Charalampopoulou and Toby Tyrrell also acknowledge financial support from the "European Project on Ocean Acidification" (EPOCA) which received funding from the European Community's Seventh Framework Programme (FP7/2007-2013) under grant agreement no. 211384.

Edited by: K. Suzuki

Reviewed by: M. Saavedra-Pellitero and one anonymous referee

\section{References}

Abramoff, M. D., Magelhaes, P. J., and Ram, S. J.: Image processing with ImageJ, Biophotonics Int., 11, 36-42, 2004.

Assmy, P., Henjes, J., Klaas, C., and Smetacek, V.: Mechanisms determining species dominance in a phytoplankton bloom induced by the iron fertilization experiment EisenEx in the Southern Ocean, Deep-Sea Res. Pt. II, 54, 340-362, 2007.

Bakker, D. C. E., Jones, E. M., and Riley, J.: Carbon Parameters, Cruise Report No. 39, RRS James Clark Ross Cruise JC031, Hydrographic sections of Drake Passage, edited by: Hamersley, D. and McDonagh, E., National Oceanography Centre, Southampton, 51-57, 2009.

Bakker, D., McDonagh, E., Stinchcombe, M., and Messias, M.: Carbon Dioxide, Hydrographic, and Chemical Data Obtained During the R/V James Cook JC031 Cruise in the South Atlantic Ocean on CLIVAR Repeat Hydrography Section A21 (SR1, SR1b) (3 February-3 March, 2009), Carbon Dioxide Information Analysis Center, Oak Ridge National Laboratory, US Department of Energy, Oak Ridge, Tennessee, doi:10.3334/CDIAC/OTG.CLIVAR_A21_JC031_2009, 2013.
Balch, W. M., Fritz, J. J., and Fernandez, E.: Decoupling of calcification and photosynthesis in the coccolithophore Emiliania huxleyi under steady-state light-limited growth, Mar. Ecol.-Prog. Ser., 142, 87-97, 1996.

Balch, W. M., Drapeau, D. T., and Fritz, J. J.: Monsoonal forcing of calcification in the Arabian Sea, Deep-Sea Res. Pt. II, 47, 13011337, 2000.

Balch, W. M., Poulton, A. J., Drapeau, D. T., Bowler, B. C., Windecker, L. A., and Booth, E. S.: Zonal and meridional patterns of phytoplankton biomass and carbon fixation in the Equatorial Pacific Ocean, between $110^{\circ} \mathrm{W}$ and $140^{\circ} \mathrm{W}$, Deep-Sea Res. Pt. II, 58, 400-416, 2011.

Balch, W. M., Drapeau, D. T., Bowler, B. C., Lyczkowski, E. R., Lubelczyk, L. C., Painter, S. C., and Poulton, A. J.: Surface biological, chemical and optical properties of the Patagonian Shelf coccolithophore bloom, the brightest waters of the Great Calcite Belt, Limnol. Oceanogr., 59, 1715-1732, 2014.

Balch, W. M., Bates, N. R., Lam, P. J., Twining, B. S., Rosengard, S. Z., Bowler, B. C., Drapeau, D. T., Garley, R., Lubelczyk, L. C., Mitchell, C., and Rauschenberg, S.: Factors regulating the Great Calcite Belt in the Southern Ocean and its biogeochemical significance, Global Biogeochem. Cy., 30, 1124-1144, doi:10.1002/2016GB005414, 2016.

Barnett, T. P., Pierce, D. W., AchutaRao, K. M., Gleckler, P. J., Santer, B. D., Gregory, J. M., and Washington, W. M.: Penetration of human-induced warming into the world's oceans, Science, 309, 284-287, doi:10.1126/science.1112418, 2005.

Baumann, K.-H., Andruleit, H. A., and Samtleben, C.: Coccolithophores in the Nordic Seas: comparisons of living communities with surface sediment assemblages, Deep-Sea Res. Pt. II, 47, 1743-1772, 2000.

Beaufort, L., Probert, I., De Garidel-Thoron, T., Bendiff, E. M., Ruiz-Pino, D., Metzl, N., Goyet, C., Buchet, M., Coupel, P., Grelaud, M., Rost, B., Rickaby, R. E. M., and de Vargas, C.: Sensitivity of coccolithophores to carbonate chemistry and ocean acidification, Nature, 476, 80-83, doi:10.1038/nature10295, 2011.

Boyd, P. W., Doney, S. C., Strzepek, R., Dusenberry, J., Lindsay, K., and Fung, I.: Climate-mediated changes to mixed-layer properties in the Southern Ocean: assessing the phytoplankton response, Biogeosciences, 5, 847-864, doi:10.5194/bg-5-8472008, 2008.

Brand, L. E.: Minimum iron requirements of marine phytoplankton and the implications of the biogeochemical control of new production, Limnol. Oceanogr., 36, 1756-1771, 1991.

Charalampopoulou, A.: Coccolithophores in high latitude and polar regions: relationships between community composition, calcification and environmental factors, $\mathrm{PhD}$ thesis, University of Southampton, UK, 139 pp., 2011.

Charalampopoulou, A., Poulton, A. J., Tyrrell, T., and Lucas, M. I.: Irradiance and $\mathrm{pH}$ affect coccolithophore community composition on a transect between the North Sea and the Arctic Ocean, Mar. Ecol.-Progr. Ser., 431, 25-43, doi:10.3354/meps09140, 2011.

Clarke, K. R.: Non-parametric multivariate analyses of changes in community structure, Aust. J. Ecol., 18, 117-143, 1993.

Clarke, K. R. and Gorley, R. N.: PRIMER Version 6: User Manual/Tutorial, E-PRIMER, Plymouth, England, 91 pp., 2006.

Cook, S. S., Whittcock, L., Wright, S. W., and Hallegraeff, G. M.: Photosynthetic pigment and genetic differences between two 
southern Ocean morphotypes of Emiliania huxleyi (Haptophyta), J. Phycol., 47, 615-626, 2011.

Cook, S. S., Jones, R. C., Vaillancourt, R. E., and Hallegraeff, G. M.: Genetic differentiation among Australian and Southern Ocean populations of the ubiquitous coccolithophore Emiliania huxleyi (Haptophyta), Phycologia, 52, 368-374, 2013.

Crawford, D. W., Lipsen, M. S., Purdie, D. A., Lohan, M. C., Statham, P. J., Whitney, F. A., Putland, J. N., Johnson, W. K., Sutherland, N., Peterson, T. D., Harrison, P. J., and Wong, C. S.: Influence of zinc and iron enrichments on phytoplankton growth in the north-eastern subarctic Pacific, Limnol. Oceanogr., 48, 1583-1600, 2003.

Cubillos, J. C., Wright, S. W., Nash, G., de Salas, M. F., Griffiths, B., Tilbrook, B., Poisson, A., and Hallegraeff, G. M.: Calcification morphotypes of the coccolithophorid Emiliania huxleyi in the Southern Ocean: changes in 2001 to 2006 compared to historical data, Mar. Ecol.-Prog. Ser., 348, 47-54, doi:10.3354/meps07058, 2007.

Delille, B., Barlay, J., Zondervan, I., Jacquet, S., Chou, L., Wollast, R., Bellerby, R. G. J., Frankignoulle, M., Vieira Borges, A., Riebesell, U., and Gattuso, J. P.: Response of primary production and calcification to changes of $p \mathrm{CO}_{2}$ during experimental blooms of the coccolithophorid Emiliania huxleyi, Global Biogeochem. Cy., 19, GB2023, doi:10.1029/2004GB002318, 2005.

Dickson, A. G., Sabine, C. L., and Christian, J. R.: Guide to best practices for ocean $\mathrm{CO}_{2}$ measurements, PICES Special Publication, 3, Sidney, Canada, 191 pp., 2007.

Dong, S., Sprintall, J., Gille, S. T., and Talley, L.: Southern Ocean mixed-layer depth from Argo float profiles, J. Geophys. Res., 113, 2156-2202, doi:10.1029/2006jc004051, 2008.

Eynaud, F., Giraudeau, J., Pichon, J. J., and Pudsey, C. J.: Seasurface distribution of coccolithophores, diatoms, silicoflagellates and dinoflagellates in the South Atlantic Ocean during the late austral summer 1995, Deep-Sea Res. Pt. I, 46, 451-482, 1999.

Feng, Y., Warner, M. E., Zhang, Y., Sun, J., Fu, F.-X., Rose, J. M., and Hutchins, D. A.: Interactive effects of increased $p \mathrm{CO}_{2}$, temperature and irradiance in the marine coccolithophore Emiliania huxleyi (Prymnesiophyceae), Eur. J. Phycol., 43, 87-98, 2008.

Fernandez, E., Boyd, P., Holligan, P. M., and Harbour, D. S.: Production of organic and inorganic carbon within a large-scale coccolithophore bloom in the northeast Atlantic Ocean, Mar. Ecol.Prog. Ser., 97, 271-285, 1993.

Findlay, C. S. and Giraudeau, J.: Extant calcareous nannoplankton in the Australian Sector of the Southern Ocean (austral summers 1994 and 1995), Mar. Micropalaeontol., 40, 417-439, 2000.

Fowler, J., Cohan, L., and Jarvis, P.: Practical statistics for field biology, John Wiley \& Sons Ltd, Chichester, England, 257 pp., 1998.

Garcia, V. M. T., Garcia, C. A. E., Mata, M. M., Pollery, R. C., Piola, A. R., Signorini, S. R., McClain, C. R., and IglesiasRodriguez, M. D.: Environmental factors controlling the phytoplankton blooms at the Patagonian Shelf-break in spring, DeepSea Res. Pt. I, 55, 1150-1166, 2008.

Gravalosa, J. M., Flores, J. A., Sierro, F. J., and Gersonde, R.: Sea surface distribution of coccolithophores in the eastern sector of the Southern Ocean (Bellignshausen and Amundsen Seas) during the late austral summer of 2001, Mar. Micropalaeontol., 69, 1625,2008 .
Gruber, N.: Warming up, turning sour, losing breath: ocean biogeochemistry under global change, Philos. T. Roy. Soc. A, 369, 1980-1996, 2011.

Hagino, K., Bendif, E. M., Young, J. R., Kogame, K., Probert, I., Takano, Y., Horiguchi, T., de Vargas, C., and Okada, H.: New evidence for morphological and genetic variation in the cosmopolitan coccolithophore Emiliania huxleyi (Prymnesiophyceae) from the coxlb-ATP4 genes, J. Phycol., 47, 1164-1176, 2011.

Harley, J., Borges, A. V., Van De Zee, C., Delille, B., Godoi, R. H. M., Schiettecatte, L.-S., Roevros, N., Aerts, K., Lapernat, P.E., Rebreanu, L., Groom, S., Daro, M.-H., Van Grieken, R., and Chou, L.: Biogeochemical study of a coccolithophore bloom in the northern Bay of Biscay (NE Atlantic Ocean) in June 2004, Progr. Oceanogr., 86, 317-336, 2010.

Hauri, C., Friedrich, T., and Timmermann, A.: Abrupt onset and prolongation of aragonite under-saturation events in the Southern Ocean, Nature Climate Change, 6, 172-176, doi:10.1038/nclimate2844, 2015.

Hinz, D. J., Poulton, A. J., Nielsdottir, M. C., Steinberger, S., Korb, R. E., Achterberg, E. P., and Bibby, T. S.: Comparative seasonal biogeography of mineralising nannoplankton in the Scotia Sea: Emiliania huxleyi, Fragilariopsis spp. and Tetraparma pelagica, Deep-Sea Res. Pt. II, 59-60, 57-66, 2012.

Holligan, P. M., Groom, S. B., and Harbour, D. S.: What controls the distribution of the coccolithophore, Emiliania huxleyi, in the North Sea?, Fish. Oceanogr., 2, 175-183, 1993.

Holligan, P. M., Charalampopoulou, A., and Hutson, R.: Seasonal distribution of the coccolithophore Emiliania huxleyi and of particulate inorganic carbon in the surface waters of the Scotia Sea, J. Mar. Syst., 82, 195-205, 2010.

Jin, X., Liu, C., Poulton, A. J., Dai, M., and Guo, X.: Coccolithophore responses to environmental variability in the South China Sea: species composition and calcite content, Biogeosciences, 13, 4843-4861, doi:10.5194/bg-13-4843-2016, 2016.

Johnson, K. M., Williams, P. J. L., Brändström, L., and Sieburth, J. M.: Coulometric total carbon dioxide analysis for marine studies: automatization and calibration, Mar. Chem., 21, 117-133, 1987.

Kirk, J. T. O.: Light and photosynthesis in aquatic ecosystems, Cambridge University Press, Cambridge, 401 pp., 1983.

Kirkwood, D.: Nutrients: Practical notes on their determination in seawater, ICES Techniques in marine environmental sciences, No. 17, International Council for the Exploration of the Sea, Copenhagen, Denmark, 1996.

Lam, P. J., Tortell, P. D., and Morel, M. M.: Differential effects of iron additions on organic and inorganic carbon production by phytoplankton, Limnol. Oceanogr., 46, 1199-1202, 2001.

Langer, G., Nehrke, G., Probert, I., Ly, J., and Ziveri, P.: Strain-specific responses of Emiliania huxleyi to changing seawater carbonate chemistry, Biogeosciences, 6, 2637-2646, doi:10.5194/bg-6-2637-2009, 2009.

Langer, G., Probert, I., Nehrke, G., and Ziveri, P.: The morphological response of Emiliania huxleyi to seawater carbonate chemistry changes: an inter-strain comparison, J. Nannoplankt. Res., 32, 29-34, 2011.

Levitus, S., Antonov, J. I., Boyer, T. P., and Stephen, C.: Warming of the world ocean, Science, 287, 2225-2229, 2000.

Linschooten, C., Bleijswijk, J. D. L., van Emburg, P. R., de Vrind, J. P. M., Kempers, E. S., Westbroek, P., and de Vrind-de Jong, E. $\mathrm{Q} .:$ Role of the light-dark cycle and medium composition on the 
production of coccoliths by Emiliania huxleyi (Haptophyceae), J. Phycol., 27, 82-86, 1991.

Lohbeck, K. T., Riebesell, U., and Reusch, T. B. H.: Adaptive evolution of a key phytoplankton species to ocean acidification, Nat. Geosci., 5, 346-351, doi:10.1038/ngeo1441, 2012.

Malinverno, E., Triantaphyllou, M. V., and Dimiza, M. D.: Coccolithophore assemblage distribution along a temperate to polar gradient in the West Pacific sector of the Southern Ocean (January 2005), Micropaleontology, 61, 489-506, 2015.

McIntyre, A. and Bé, A. W. H.: Modern coccolithophores of the Atlantic Ocean - I. Placoliths and crytoliths, Deep-Sea Res., 14, 561-597, 1967.

Merico, A., Tyrrell, T., Lessard, E. J., Oguz, T., Stabeno, P. J., Zeeman, S. I., and Whiteledge, T. E.: Modelling phytoplankton succession on the Bering Sea shelf: role of climate influences and trophic interactions in generating Emiliania huxleyi blooms 1997-2000, Deep-Sea Res. Pt. I, 51, 1803-1826, 2003.

Mohan, R., Mergulhao, L. P., Guptha, M. V. S., Rajakumar, A., Thamban, M., AnilKumar, N., Sudhakar, M., and Ravindra, R.: Ecology of coccolithophores in the Indian sector of the Southern Ocean, Mar. Micropalaeontol., 67, 30-45, 2008.

Müller, M. N., Antia, A. N., and LaRoche, J.: Influence of cell cycle phase on calcification in the coccolithophore Emiliania huxleyi, Limnol. Oceanogr., 53, 506-512, 2008.

Nielsdöttir, M. C., Moore, C. M., Sanders, R., Hinz, D. J., and Achterberg, E. P.: Iron limitation of the post bloom phytoplankton communities in the Iceland Basin, Global Biogeochem. Cy., 23, GB3001, doi:10.1029/2008GB003410, 2009.

Orr, J. C., Fabry, V. J., Aumont, O., Bopp, L., Doney, S. C., Feely, R. A., Gnanadesikan, A., Gruber, N., Ishida, A., Joos, F., Key, R. M., Lindsay, K., Maier-Reimer, E., Matear, R., Monfray, P., Mouchet, A., Najjar, R. G., Plattner, G.-K., Rodgers, K. B., Sabine, C. L., Sarmiento, J. L., Schlitzer, R., Slater, R. D., Totterdell, I. J., Weirig, M.-F., Yamanaka, Y., and Yool, A.: Anthropogenic ocean acidification over the twenty-first century and its impact on calcifying organisms, Nature, 437, 681-686, doi:10.1038/nature04095, 2005.

Orsi, A. H., Whitworth III, T., and Nowlin, W. D.: On the meridional extent and fronts of the Antarctic Circumpolar Current, Deep-Sea Res. Pt. I, 42, 641-673, 1995.

Paasche, E.: A review of the coccolithophorid Emiliania huxleyi (Prymnesiophyceae), with particular references to growth, coccolith formation, and calcification-photosynthesis interactions, Phycologia, 40, 5003-5029, 2002.

Paasche, E. and Brubak, S.: Enhanced calcification in the coccolithophorid Emiliania huxleyi (Haptophyceae) under phosphorus limitation, Phycologia, 33, 324-330, 1994.

Paasche, E., Brubak, S., Skattebol, S., Young, J. R., and Green, J. C.: Growth and calcification in the coccolithophorid Emiliania huxleyi (Haptophyceae) at low salinities, Phycologia, 35, 394 403, 1996.

Pierrot, D. E., Lewis, E., and Wallace, D. W. R.: MS Excel Program Developed for $\mathrm{CO}_{2}$ System Calculations, ORNL/CDIAC105a, Carbon Dioxide Information Analysis Centre, Oak Ridge National Laboratory, US Department of Energy, Oak Ridge, Tennessee, 2006.

Poulton, A. J., Adey, T. R., Balch, W. M., and Holligan, P. M.: Relating coccolithophore calcification rates to phytoplankton commu- nity dynamics: Regional differences and implications for carbon export, Deep-Sea Res. Pt. II, 54, 538-557, 2007.

Poulton, A. J., Charalampopoulou, A., Young, J. R., Tarran, G. A., Lucas, M. I., and Quartly, G. D.: Coccolithophore dynamics in non-bloom conditions during late summer in the central Iceland Basin (July-August 2007), Limnol. Oceanogr., 55, 1601-1613, 2010.

Poulton, A. J., Young, J. R., Bates, N. R., and Balch, W. M.: Biometry of detached Emiliania huxleyi coccoliths along the Patagonian Shelf, Mar. Ecol.-Prog. Ser., 443, 1-17, doi:10.3354/meps09445, 2011.

Poulton, A. J., Painter, S. C., Young, J. R., Bates, N. R., Bowler, B., Drapeau, D., Lyczsckowski, E., and Balch, W. M.: The 2008 Emiliania huxleyi bloom along the Patagonian Shelf: Ecology, biogeochemistry, and cellular calcification, Global Biogeochem. Cy., 27, 1023-1033, doi:10.1002/2013GB004641, 2013.

Poulton, A. J., Stinchcombe, M. C., Achterberg, E. P., Bakker, D. C. E., Dumousseaud, C., Lawson, H. E., Lee, G. A., Richier, S., Suggett, D. J., and Young, J. R.: Coccolithophores on the northwest European shelf: calcification rates and environmental controls, Biogeosciences, 11, 3919-3940, doi:10.5194/bg-11-39192014, 2014.

Pollard, R. T., Lucas, M. I., and Read, J. F.: Physical controls on biogeochemical zonation in the Southern Ocean, Deep-Sea Res. Pt. II, 49, 3289-3305, 2002.

Raitsos, D. E., Lavender, S. J., Pradhan, Y., Tyrrell, T., Reid, P. C., and Edwards, M.: Coccolithophore bloom size variation in response to the regional environment of the subarctic North Atlantic, Limnol. Oceanogr., 51, 2122-2130, 2006.

Rivero-Calle, S., Gnanadesikan, A., Del Castillo, C. E., Balch, W. M., and Guikema, S. D.: Multi-decadal increase in North Atlantic coccolithophores and the potential role of rising $\mathrm{CO}_{2}$, Science, 350, 1533-1537, doi:10.1126/science.aaa8026, 2015.

Robinson, C. and Williams, P. J. L.: Development and assessment of an analytical system for the accurate and continual measurement of total dissolved inorganic carbon, Mar. Chem., 34, 157-175, 1992.

Rochford, P. A., Kara, A. B., Wallcraft, A. J., and Arnone, R. A.: Importance of solar subsurface heating in ocean general circulation models, J. Geophys. Res., 106, 30923-30938, 2001.

Saavedra-Pellitero, M., Baumann, K.-H., Flores, J.-A., and Gersonde, R.: Biogeographic distribution of living coccolithophores in the Pacific sector of the Southern Ocean, Mar. Micropaleontol., 109, 1-20, 2014.

Samtleben, C., Schafer, P., Andruleit, H., Baumann, A., Baumann, K.-H., Kohly, A., Matthiessen, J., and Schroderritzrau, A.: Plankton in the Norwegian-Greenland Sea: from living communities to sediment assemblages - an actualistic approach, Geol. Rundsch., 84, 108-136, 1995.

Sciandra, A., Harley, J., Lefevre, D., Lemee, R., Rimmelin, P., Denis, M., and Gattuso, J. P.: Response of coccolithophorid Emiliania huxleyi to elevated partial pressure of $\mathrm{CO}_{2}$ under nitrogen limitation, Mar. Ecol.-Prog. Ser., 261, 111-122, doi:10.3354/meps261111, 2003.

Smyth, T. J., Tyrrell, T., and Tarrant, B.: Time series of coccolithophore activity in the Barents Sea, from twenty years of satellite imagery, Geophys. Res. Lett., 31, L11302, doi:10.1029/2004GL019735, 2004. 
Sun, C. and Watts, D. R.: A circumpolar gravest empirical mode for the Southern Ocean hydrography, J. Geophys. Res., 106, 28332855, doi:10.1029/2000JC900112, 2001.

Taylor, J. R.: An introduction to error analysis, University Science Books, Sausalito, California, 327 pp., 1982.

Thomsen, H. A.: Identification by electron-microscopy of nanoplanktonic coccolithophorids (Prymnesiophyceae) from West Greenland, including the description of Papposphaera sarion sp. Nov, Brit. Phycol. J., 16, 77-94, 1981.

Tyrrell, T. and Charalampopoulou, A.: Coccolithophore size, abundance and calcification across Drake Passage (Southern Ocean, 2009), doi:10.1594/PANGAEA.771715, 2009.

Tyrrell, T. and Merico, A.: Emiliania huxleyi: bloom observations and the conditions that induce them, in: Coccolithophores: from molecular processes to Global Impact, edited by: Thierstein, $H$. R. and Young, J. R., Springer-Verlag, Heidelberg, 75-90, 2004.

van Bleijswijk, J., van der Wal, P., Kempers, R. S., Veldhuis, M., Young, J. R., Muyzer, G., de Vrind-de Jong, E. Q., and Westbroek, P.: Distribution of two types of Emiliania huxleyi (Prymnesiophyceae) in the northeast Atlantic region as determined by immunofluorescence and coccolith morphology, J. Phycol., 27, 566-570, 1991.

Venables, H. J. and Moore, C. M.: Phytoplankton and light limitation in the Southern Ocean: Learning from highnutrient, high-chlorophyll areas, J. Geophys. Res., 115, C02015, doi:10.1029/2009JC005361, 2010.

Welschmeyer, N. A.: Fluorometric analysis of chlorophyll $a$ in the presence of chlorophyll $b$ and phaeo-pigments, Limnol. Oceanogr., 39, 1985-1992, 1994.

Whitworth III, T.: Zonation and geostrophic flow of the Antarctic Circumpolar Current at Drake Passage, Deep-Sea Res., 21, 497$507,1980$.
Winter, A. and Siesser, W. G.: Atlas of living coccolithophores, in: Coccolithophores, edited by: Winter, A. and Siesser, W. G., Cambridge University Press, Cambridge, 107-159, 1994.

Winter, A., Elbrachter, M., and Krause, G.: Subtropical coccolithophores in the Weddell Sea, Deep-Sea Res. Pt. I, 46, 436-449, 1999.

Winter, A., Henderiks, J., Beaufort, L., Rickaby, R. E. M., and Brown, C. W.: Poleward expansion of the coccolithophore Emiliania huxleyi, J. Plankton Res., 36, 316-325, doi:10.1093/plankt/fbt110, 2014.

Young, J. R. and Ziveri, P.: Calculation of coccolith volume and its use in calibration of carbonate flux estimates, Deep-Sea Res. Pt. II, 47, 1679-1700, 2000.

Young, J. R., Geisen, M., Cros, L., Kleijne, A., Sprengel, C., Probert, I., and Østergaard, J. B.: A guide to extant coccolithophore taxonomy, J. Nannoplankt. Res., Special Issue, 1, 1132, 2003.

Young, J. R., Poulton, A. J., and Tyrrell, T.: Morphology of Emiliania huxleyi coccoliths on the northwestern European shelf - is there an influence of carbonate chemistry?, Biogeosciences, 11, 4771-4782, doi:10.5194/bg-11-4771-2014, 2014.

Zondervan, I.: The effects of light, macronutrients, trace metals and $\mathrm{CO}_{2}$ on the production of calcium carbonate and organic carbon in coccolithophores - A review, Deep-Sea Res. Pt. II, 54, 521537, doi:10.1016/j.dsr2.2006.12.004, 2007.

Zondervan, I., Rost, B., and Riebesell, U.: Effect of $\mathrm{CO}_{2}$ concentration on the PIC/POC ratio in the coccolithophore Emiliania huxleyi grown under light-limiting conditions and different day lengths, J. Exp. Mar. Biol. Ecol., 272, 55-70, 2002. 